\begin{abstract}
The initial years of transition in the Russian Federation have been characterised by relatively smaller falls in employment than in other reform-orientated countries of eastern Europe, despite the huge negative shock caused by the move from planned to market economy. Using information from two complementary household survey data sets, we show that for many Russian workers, the dominant form of labour market adjustment has instead been the delayed receipt of wages. Other forms of adjustment at the intensive margin have not been used much. Wage arrears are found across the private, state and budgetary sector in approximately equal proportions. There are large regional variations in the incidence of wage arrears. Workers in the metropolitan centre are significantly less affected by delayed and incomplete wage payments than workers in the provinces. There is less evidence that individual characteristics contribute much toward the incidence of wage arrears, though unobserved heterogeneity may have some role to play. As with the incidence of unemployment, however, there is evidence that the persistence of arrears is concentrated on a subset of the working population. We show that workers can only exercise the exit option of a job quit from a firm paying wages in arrears if the outside labour market is sufficiently dynamic.
\end{abstract}

This paper was produced as part of the Centre's Human Resources Programme 


\section{Grime and Punishment: \\ Job Insecurity and Wage Arrears in the Russian Federation}

Hartmut Lehmann, Jonathan Wadsworth and Alessandro Acquisti 
September 1998 
Series Editor: Graham Ingham

Published by

Centre for Economic Performance

London School of Economics and Political Science

Houghton Street

London WC2A 2AE

(C) H. Lehmann, J. Wadsworth and A. Acquisti, 1998

ISBN 0753012367

Individual copy price: $£ 5$ 


\section{Grime and Punishment: \\ Job Insecurity and Wage Arrears in the Russian \\ Federation}

Hartmut Lehmann, Jonathan Wadsworth and Alessandro Acquisti

1. Introduction 1

2. Data 3

3. Employment Contracts in Russia 4

4. Wage Arrears in Russia 5

$\begin{array}{lll}5 . & \text { Conclusions } & 12\end{array}$

Tables $\quad 13$

Figures $\quad 35$

Appendix $\quad 38$

$\begin{array}{ll}\text { References } & 40\end{array}$ 


\section{Acknowledgements}

For valuable comments the authors would like to thank Sarah Ashwin, Vladimir Gimpelson, Evgenyij Gontmakher, Tatyana Gorbacheva, Michael Harrison, Barry Ickes, Douglas Lippoldt, Mark Schaffer, Viktor Starodubrovsky, Ruslan Yemtsov and participants at the conferences 'Labor Markets in Transition', University of Michigan, 17-19 October 1997 and 'Economic Transition in CEE and Russia, Theory and Empirical Evidence', EERC (Russia), Moscow, 13 December 1997 and seminar presentations at the Catholic University of Leuven, the London School of Economics and Trinity College, Dublin. Financial support from the European Commission (TacisAce Project No. T94-1073-R) is gratefully acknowledged.

Hartmut Lehmannis at Trinity College Dublin and William Davidson Institute, University of Michigan Business School, Ann Arbor. Jonathan Wadsworth is at the Centre for Economic Performance, London School of Economics and Royal Holloway College, University of London. Alessandro Acquisti is at Trinity College Dublin. 


\section{Grime and Punishment: Job Insecurity and Wage Arrears in the Russian Federation}

\section{Hartmut Lehmann, Jonathan Wadsworth and Alessandro Acquisti}

"All these new ideas, reforms, theories, have penetrated even to us in the provinces, but to see the whole picture and see it clearly, one must be in the capital" Dostoevsky, Crime and Punishment, 1866

\section{Introduction}

Five years into transition, the Russian labour market still seems to be different from labour markets in other reform-oriented transition economies. Despite falling state spending, hardening budget constraints, a loosening of price controls, exposure to international competition and an ensuing 30$40 \%$ fall in aggregate output since 1992, the claimant unemployment rate is still under $4 \%$ and employment has fallen by less than $10 \%$, both less dramatic changes than observed elsewhere, (Russian Economic Trends 1997). Continued uncertainty surrounding the transition process has led to a series of conflicts over enterprise funds between the tax authorities, the banks and the workforce, between enterprises and their regional governments, between the regions and the centre.

Against this background of uncertainty and negative economic shocks, aggregate employment levels remain relatively high. Why this may be so is the subject of this paper. If employment has not fallen much, it is possible that firms have adjusted to contractions in sales of their goods and growing liquidity constraints in other ways. Adjustments on the intensive, rather than the extensive, margin such as involuntary unpaid leave of absence, a reduction in hours worked, or the increased use of temporary contract working are all possibilities. Commander, McHale and Yemtsov (1995) and Foley (1995) have mooted that a higher degree of employment instability may be more common in the emerging private sector, where, in a climate of uncertainty, workers may be more vulnerable to layoffs and short-term contracts than in the state sector. A further potential source of insecurity could be that employees, even those with permanent contracts, are faced with compulsory reductions in working hours. Moreover, some firms may tell their workers not to report for work whilst not making them redundant. In so doing, the enterprise avoids salary expenses and does not have to make redundancy payments.

There may also be another way for firms to cope with the effects of transition. Price, rather than quantity, adjustment through the non-payment of wages is an alternative means by which firms could have adjusted their cost schedules. There is little doubt that the problem has worsened in recent years. Wage arrears have risen by around 50\% since the beginning of 1996. Goskomstat figures put the aggregate stock of arrears at the beginning of 1997 at around 50 trillion roubles, some $138 \%$ of the monthly wage bill, (Russian Economic Trends 1997). As yet there is little hard evidence at the micro level. This paper attempts to help fill that gap.

Standing (1996a, b) presents establishment-level evidence of large regional variations in the proportion of firms who had experienced 'a lot' of wage arrears. However this data is only qualitative. Alfandari and Schaffer (1996) conclude that, on their evidence from a sample of firms, wage arrears do not pose a major problem in the Russian Federation. They believe that wage arrears are small when compared to trade arrears, uncorrelated with severe financial 
distress and mainly used by management to extract tax concessions from the government. Certainly, the collection of tax revenues is a priority of the federal government. Clarke, Ashwin and Borisov (1997), suggest that these implicit or explicit agreements between the federal government and the banks over the seconding of enterprise bank deposits in order to meet federal tax and debt liabilities has left many firms with little cash to pay wages, irrespective of the firm's profitability. A lack of credit facilities in the banking sector then exacerbate this cash flow problem.

There are other potential contributory factors. One idea is that wage arrears are a form of forced loan from workers with few outside opportunities to firms in genuine distress. If the firm is dominated by insiders with vested interests in the continued existence of the enterprise then such loans will be more likely. If the firm is in distress, the workers' only outlet under existing law, is to sue the firm for bankruptcy. So what may arise is a form of implicit contract, whereby the worker trades wage arrears for continued employment. Compounding this, is the role of central government in paying off its budgetary arrears by delaying payment for state orders and refusing to release funds for the payment of wages in the budgetary sector, ( $\mathrm{g}$ health, education, public administration).

There may be large regional variation underlying country-wide events, depending on the industrial structure, the extent of transformation, the regional government's response to shocks and its relationship with the centre. Also, certain types of workers could be disproportionately affected. No one has addressed the issue whether firms discriminate against certain workers in their application of wage arrears, ${ }^{1}$ whether patronage is an important element or whether firms use efficiency wage type considerations to retain the most productive members of its workforce.

If so, these methods could have made jobs less secure for many Russian workers. There is, however, little hard evidence on the extent to which such adjustment strategies have been applied. This paper tries to provide some evidence using household survey data. We analyse all these aspects of labour market behaviour using two individual-level data sources. The first, a supplement to the March 1996 Russian Labour Force Survey (RLFS), in five representative regions with which to analyse in detail regional variations across industries, firm types and individuals. The second is the Russian Longitudinal Monitoring Survey (RLMS), a smaller, but nationally sampled longitudinal survey of individuals, covering many of the same issues as in the RLFS supplement and following its sample population over the period 1994 to $1996 .{ }^{2}$ Desai and Idson (1997) use the RLMS to focus on household characteristics of those in arrears and the likelihood that this induces bartering among those affected. We extend their analysis by introducing more establishment characteristics and exploit the panel nature of the RLMS to examine individual dynamics and the persistence of wage arrears.

Whilst the problem of wage arrears may stem from the economic position of the firm and the institutional structure during transition, we believe that responses by individuals can shed light on some areas that would otherwise be difficult to obtain from an analysis of firms alone. Using these two complementary data sets, we can examine how insecure employment really is in the Russian labour market, which individuals and which sectors are most affected by it and begin to build up a picture of the evolution of some of these trends across time.

1. Layard and Richter (1995) give a cross-tabulation of the extent of 1994 wage arrears using a VCIOM survey of individuals, while Gordon (1997), using VCIOM data, shows the overall rising incidence of wage arrears between 1992 and 1996.

2. The supplement was developed by the authors, Evgenyi Gontmacher, Ingrid Leiprecht, Douglas Lippoldt, Viktor Starodubrovskyi aand Ruslan Yemtsov with the TACIS-Ace project - The Performance of Regional Labour Market Types in the Russian Federation (T94-1073-R). 


\section{Data}

Much of our analysis is based on the March 1996 round of the Russian Labour Force Survey (RLFS), conducted by the national and regional offices of Goskomstat. The basic survey asks standard ILO-type questions about employment, job search and related issues to a random sample of households in all regions of the Russian Federation. A supplement, tailored to our research, was added to the original survey in five Russian regions. The five regions, Moscow City, Moscow Oblast, Chuvash Republic, Chelyabinsk and Krasnoyarski Krai, were selected because of their varied nature and the fact that they can be considered representative of the diffuse labour market types throughout the Russian Federation. The appendix gives a brief description of these regions and the questions in the supplement. More than 17,000 households were interviewed in these regions, leading to more than 25,000 individual records on the population of working age. There were 10043 observations in Moscow, 7082 in Moscow Oblast, 3449 in Krasnoyarsk, 3592 in Chelyabinsk and 1488 in the Chuvash Republic. Responses by military/security personnel are limited and so are excluded from the analysis. Some of the variables analysed in the paper industry and the decomposition of ownership into de novo and privatised firms - could only be ascertained from questions in the RLFS supplement.

Our second data source is the second phase of the Russian Longitudinal Monitor Survey (RLMS), a longitudinal panel of around 4000 households across the Russian Federation conducted in the Fall of each year since 1994. Like the RLFS, the data contains a set of demographic and establishment characteristics, not always the same as in the RLFS, together with information on the labour market activities of its sample. Despite, its relatively small size, the main advantage of this source for our purposes, is that we can track individuals and the incidence of wage arrears over time and control for any unobserved individual heterogeneity that may have on effect on the probability of being paid in arrears. For example, if patronage is an important determinant of arrears then this will be unobserved, but failure to account for this may bias our results. As with the RLFS we restrict our sample to employees of working age, excluding the military. ${ }^{3}$ In order to focus on the build up of wage arrears over time, we impose the additional sample restriction that the individual appear in the survey in every wave. This gives us a total sample of 8700 observations over the three waves of which around 3500 are in work at any wave.

The survey questions which deal with wage arrears are complementary across the two surveys. Both ask question of the form, "Does your place of work owe you any money?" The RLFS supplement then asks for the month in which workers were last paid and the type of payment made by the firm, ranging from complete and on time, to late and incomplete. The RLMS asks simply "How much money have in all they not paid you?" Respondents in both surveys are asked to state the amount of money received from their employers after tax in the past month. There is no distinction made between basic wages and any bonus. These wage responses are then deflated by a national price deflator indexed to 100 at January 1996. ${ }^{4}$ There is no indication whether wage arrears are estimated before or after tax.

\section{Employment Contracts in Russia}

3. The RLMS is ambiguous on the nature of self-employment, referring instead to the extent of self-ownership in the enterprise where the individual works. We exclude only those who say they own between 51 and $100 \%$ of the enterprise.

4. There are no population weights in either data set. 
Even the Soviet labour market had substantial regional disparities. There were both excess labour supply, 'open unemployment', regions (mainly the Central Asian Republics and the Caucasus) and labour deficient areas, where chronic excess demand for labour was observed. The latter dominated what is now the Russian Federation, (Malle, 1990). Enterprises were continuously on the lookout for workers, guaranteeing permanent employment contracts to virtually all workers, including the newly hired. At the heart of labour relations was an employment culture that combined full employment with job security. This coexistence came about because it was in the economic interest of enterprises to engage in labour hoarding continuously. It was not the result of a political commitment to permanent employment for the entire workforce (Hanson, 1986 and Nuti, 1986). Five years into transition, the economic environment has changed radically for enterprises throughout the Russian Federation. How has this affected the incidence of permanent employment?

The three types of employment contracts that workers can enter, permanent, fixed term and one-off contracts are outlined in Table 1. There is little variation in these variables across age, gender and region. The vast majority of the employed have a permanent contract. Only for those older than 60 years is there a noticeably higher proportion of fixed term contracts. Having a permanent contract does, of course, not mean that one cannot be made redundant. Nevertheless it is clear that in March 1996 only a small fraction of workers in these five regions had, on this measure, uncertain job prospects. ${ }^{5}$

It is true, however, that short-term contracts are more prevalent in the stock of workers with new jobs, those with tenure 12 months or less. Around 1 in 9 new jobs are not regarded as permanent. Since new jobs are at the margin of adjustment, it may be that this is an indication of greater insecurity in the labour market to come, though these numbers are still low by some western standards. ${ }^{6}$ To highlight the main determinants we present probit estimates of the incidence of permanent contracts in Table 2 for those in jobs for less than 12 months. Workers over 55 years of age and those working less than 30 hours a week have substantially lower probabilities of having a permanent contract. There is now evidence of a clear regional progression between the metropolitan area and the provinces. The typical worker entering a new jobs in Moscow is around 9 percentage points more likely to be on a temporary contract than the typical worker in Chelyabinsk. Those in a firm with more than 5 employees and in a state-owned or privatised firm raises the probability of having a permanent contract by around 8 and between 7 percentage points respectively. In sum, if the type of contract is taken as a measure of job security, new jobs do seem less secure than all jobs, particularly in small firms and in the de novo private sector. This is one more piece of evidence that de novo private firms in Russia behave differently from state-owned and privatised firms (see Richter and Schaffer, 1996). There is no significant difference across industrial sectors, once other characteristics are controlled for.

When asked about employment, respondents may associate this with the enterprise where they have deposited their 'labour book', whether they actually work there or not. Nearly all those who have deposited their 'labour book' with an enterprise will have a permanent contract. For this reason, it is useful to see how many hours those who claim to have a permanent contract actually worked in their primary employment during the reference week and to compare these with the usual hours worked. Table 3 shows how the difference in actual and usual hours worked is distributed. The majority of individuals, $(91 \%)$, worked the same hours as usual, while $6.5 \%$ worked less and $3.5 \%$ more. Nearly half of those who worked less were on zero hours. This

5. More than $90 \%$ of those on fixed term contracts would have preferred to have a permanent contract.

6. Gregg and Wadsworth (1996) show that the proportion of temporary jobs in the stock of new jobs in Britain is around $17 \%$. 
suggests that about $3 \%$ of the sample were on leave. About half of this group, (1.5\% of the total sample of employed workers), had not received a wage in March or February, ie they were on unpaid leave during the reference week. ${ }^{7}$

There is some variation at regional level, with a spread of 9 percentage points between the Chuvash Republic, where we observe the highest value and Moscow City, where only 5\% of workers worked fewer than normal hours. Nearly $60 \%$ of those working less than their usual hours in Chuvash, ie about $7 \%$ of employees with permanent contracts, were on zero hours during the reference week. In Moscow City, this figure was only 2.5\%. The proportion working more than usual is particularly high in Krasnoyarsk, where mining and mineral extraction feature prominently. Despite these regional variations, it appears that the overwhelming majority of employees had a permanent contract and a full workload in the spring of 1996.

Insecure employment can also appear in the form of part-time work, ${ }^{8}$ if substantial segments of the workforce with permanent employment contracts worked involuntarily part-time. For the five regions combined about three-quarters of workers who engaged in part-time work did so involuntarily, as Table 3 demonstrates. There are variations across regions. Moscow City has less than two-thirds involuntary part-timers and the Chuvash Republic has more than $95 \%$. The overall incidence of part-time employment varies between 5\% in Krasnoyarsk and $2.8 \%$ in Chelyabinsk. Again, these are not dramatic numbers. Short-time work does not seem to be the route by which enterprises maintain employment levels.

\section{Wage Arrears in Russia}

The evidence so far does not point to insecure labour market experience on the intensive margin for most of the employed workforce. Given the moderate fall of employment relative to output during the first 4 years of transition, ${ }^{9}$ this seems remarkable. One possible explanation is that there has been wage flexibility (Layard and Richter, 1995). At the end of 1995, average real wages had, according to Goskomstat (1996b), fallen to around 34\% of the level observed before transition began (January 1992). ${ }^{10}$ Another price adjustment mechanism used by enterprises to counter output shocks is the delay of wage payments to workers. By March 1996, wage arrears for the entire economy exceeded one month's wage bill (Goskomstat, 1996b).

As can be seen from Table 4, the number of workers affected by arrears is huge. In the March 1996 round of the RLFS only 60 percent of workers received their last wage in full and on time, the proportion for women being 5 percentage points higher than for men. About a quarter of employees received a wage on time, but were not paid in full, whilst around $11 \%$ received their wage late and not in full. A further $2.7 \%$ were paid in full, but not on time. According to the RLMS, $60 \%$ of the employed workforce were in arrears across the whole country in 1996, up from

7. Standing (1996b) finds that $15.2 \%$ of workers in the metals sector and $9.2 \%$ in textiles were on unpaid leave, using a survey of Russian enterprises in May 1995.

8. In the RLFS questionnaire respondents are asked whether in the reference week they worked full- or parttime and if the latter whether they did so against their wishes.

9. According to Goskomstat (1996a) employment fell between the beginning of 1992 and the end of 1995 by about $7 \%$, while GDP fell by around $40 \%$. Production in medium and large enterprises shrank by $60 \%$ over the same period (Russian Economic Trends 1995, Vol. 4, No.4).

10. Given the long queues in a supply constrained system and a large monetary overhang before the onset of reforms, the drop in real wages expressed by these official figures seems rather large. 
$40 \%$ in 1994 . There is not much variation across age groups, although those 30 years and younger seem to do a little better.

Variation in wage arrears is substantial across regions, (upper panel of Table 5). In Moscow City more than three-quarters of all employees received a complete wage on time, while in Chelyabinsk only one-third did so. In Moscow City and Moscow Oblast an average 6\% of employees have been paid an incomplete wage not on time, while the average is around $24 \%$ for the two worst performing regions, Krasnoyarsk and Chelyabinsk. ${ }^{11}$ The proportion receiving wages 'incomplete but on time' in the three provincial regions is larger than those who had been paid in full and on time. On the basis of these figures it is hard to maintain the hypothesis that wage arrears are not a major problem in parts of the Russian Federation.

One explanation for the divergent performance of regions could simply be that, as a result of political lobbying, workers in the budgetary sector receive their wages complete in the centre but not in the provinces. ${ }^{12}$ The data do not support this hypothesis as the middle panel of Table 5 shows. If anything, workers in the budgetary sector in the provinces have a higher incidence of complete wage payments than the average. The worst offenders are not government agencies but state firms in 'production', ${ }^{13}$ as the bottom panel of Table 5 shows. For this sector we observe a rise in the proportion of arrears amounting to roughly 10 percentage points for the provincial regions and Moscow Oblast and around 15 percentage points for the city of Moscow. The coefficient of variation of the proportion of arrears across regions falls from 0.40 to 0.36 as one goes from the economy as a whole to the budgetary sector, rising to 0.46 in state-owned production. The budgetary sector accounts for $35 \%$ of employment and $30 \%$ of all those in arrears. In no region is this ranking reversed. This must imply that, in March 1996, differential regional transfers of government funds cannot be the main reason for regional divergence in wage arrears.

The industrial composition of the regions could be an important factor in the divergent performance of the five regions. Certain industries were hit harder by the transformation process and the legacy of planning has left certain regions with a disproportionate share of industries in distress. As Table 6 demonstrates, there are indeed certain industrial sectors, which are particularly bad offenders. Only around $30 \%$ of all employees in mining received their wage complete and on time. Agriculture and manufacturing are the other two sectors which perform poorly, (43\% and $48 \%$ respectively). For workers in distribution/trade and finance, wage arrears do not seem to pose a major problem. Only $14 \%$ and $8 \%$ of workers in these sectors are in arrears, respectively.

To see which factors are statistically significant, we estimate probit regressions of the

11. Of the 8 regions identified in the RLMS, the incidence of arrears in 1996 was $31.7 \%$ Metropolitan, $69.1 \%$ North West, 49.3\% Central, 66.3\% Volga, 65.6\% Caucasus, 62.9\% Urals, 65.7\% Western Siberia and 67.9\% East.

12. In March 1996 around $42 \%$ of all employees still worked in the budgetary sector. Those in state-owned firms in other services, transport, distribution and trade, health and education and finance are considered as being in the budgetary sector.

13. Workers of the 'state firm production sector' are in state-owned firms in agriculture, manufacturing, construction and mining.

14. One explanation of this result could be the presidential elections in 1996. Before the election the federal government tried to pay wages in the budgetary sector wherever possible. After the election it reverted to its usual practice of withholding wages for the provincial regions. The aggregate data on nation wide wage arrears for 1996 would need to show a sharp increase for the second half of that year to make this story truly convincing. However, we do not observe, such dynamics (Russian Economic Trends, 1/97). 
incidence of wage arrears. The estimates in Table 7 show that within regions, enterprise characteristics are the main determinants of wage arrears. The larger the enterprise the higher the probability of experiencing wage arrears. Working in finance lowers the probability of wage arrears by 24 percentage points relative to working in other services, (the default), whilst employment in manufacturing and mining raises this probability by 9 and 15 percentage points respectively. Ownership type is not a significant predictor of the incidence of wage arrears. Among the occupational groups only clerks have a lower incidence of wage arrears compared to the default group of managers. Of the demographic factors only gender is important. Women are around 3 percentage points less likely to experience wage arrears, other things equal.

A third, notable result concerns the regions. Having controlled for the demographic and skill composition of the workforce, ownership and industrial structure, the regression points to the overriding importance of regional location for the incidence of wage arrears. The marginal effects of residing in Moscow City or Moscow Oblast are 35 and 31 percentage points lower than for workers in the provinces. The results of a probit regression for the budgetary sector alone confirm this dominance of the regional variables. ${ }^{15}$ The marginal effects for the metropolitan centre are of the same order of magnitude in both regressions and, therefore, seem to confirm that workers in the budgetary sector in provincial regions are no worse affected by arrears than other workers.

The wide variation of wage arrears is demonstrated in Table 8 which presents estimated arrears probabilities for workers with selected characteristics. A male with secondary education in a large mining firm in Chelyabinsk or Krasnoyarsk has a 90\% probability of being in arrears. In contrast, a female with higher education in a small financial firm in Moscow has an extremely small probability of not being paid on time and in full (1.4\%). While regional location is an overriding factor, it is true that workers in a healthy industry but in a provincial region have on average a far lower incidence of wage arrears than workers in a poorly performing industry residing in Moscow. Finally, individuals with similar characteristics have roughly the same wage arrears probabilities in the budgetary sector. We take this as further evidence that employers from the budgetary sector are not the worst offenders.

Regressions within industries (Table 9) confirm the general previous results. Demographic characteristics play a lesser role in the determination of wage arrears than do characteristics related to the establishment and the region. Regional location is the most powerful predictor of wage arrears in all industries. The regional effect is particularly strong in mining, where we have pooled the provincial regions and the two metropolitan areas. The incidence of wage arrears is, in 5 out of 9 industries, an increasing function of establishment size while ownership type is only statistically significant in 3 industries. Employment in a de novo private or privatised firm in manufacturing, reduces the incidence of wage arrears on average by 10 and 7 percentage points respectively, whilst transport workers in newly established firms are around 16 points less likely to have been paid on time and in full. Like the results from Table 7, the industry regressions, however, do not generally reveal that ownership type is an important factor in the determination of wage arrears. Longer job tenure strongly implies a higher incidence of wage arrears in transport and other services. The latter result might be explained by the relative ease with which wage concessions can be extracted from long-serving insiders of the firm. In most industries, men are less often paid wages in full and on time, the only exception being manufacturing where a male worker's probability of experiencing wage arrears is 4 percentage points lower. Variables relating to age, educational attainment and occupation are of limited or no significance.

Regional regressions, (Table 10), confirm the robustness of the results from the full sample. Industry affiliation and firm characteristics matter most in the determination of wage arrears.

15. The results of this regression are available from the authors on request. 
Mining firms withholding wages from their workers seem to be concentrated in the two provincial regions, Krasnoyarsk and Chelyabinsk, and finance and manufacturing are not significantly different from the default category other services in Chelyabinsk. In all regions but Krasnoyarsk, larger establishment size implies a higher incidence of wage arrears, while the ownership variable is either insignificant or produces ambiguous results. In this context, it is particularly interesting that only in Krasnoyarsk does working in a de novo private firm coincide with prompt wage payments. In the provinces, higher educational attainment lowers the probability of wage arrears and primeage workers are particularly hard hit in all regions apart from Chuvashy.

\section{Evidence from RLMS 1994-1996}

As Figure 1 shows, the problem of wage arrears became more acute between 1994 and 1996. The distribution of arrears moves to the right and becomes flatter, indicating that arrears are increasing and becoming more widespread over this period. In 1994, the distribution is concentrated around the 300,000 rouble level, roughly equivalent to the average monthly salary. By 1996, the distribution of arrears is less concentrated around the peak. Figure 2 plots the wage and arrears distributions together in order to gauge the size of the arrears bill. Again, it is apparent that the distribution of wage arrears has grown relative to the completed wage bill. According to the RLMS, the incidence of wage arrears grew from $43 \%$ in 1994 to $45 \%$ in 1995 and $62 \%$ in 1996. As one means of determining whether personal characteristics matter for the incidence of arrears, Figure 3 compares the initial monthly wage distribution of those who subsequently experienced arrears with those in the sample who did not. The wage distribution of those subsequently in arrears lies a little to the left of those who are not in arrears in the following period, indicating that, if anything, arrears affect those in the lower parts of the wage distribution, though the differences are not large.

Table 11 presents the results of probit estimates on the incidence of wage arrears across the Russian Federation using the RLMS. We present the results from simple pooling across the three waves alongside random effects estimates, which control for heterogeneity. Assuming that this heterogeneity is time invariant so that

$$
\mathrm{A}^{*}{ }_{\mathrm{it}}=\mathrm{X}^{\prime}{ }_{\mathrm{it}} \mathrm{B}+\mathrm{v}_{\mathrm{it}} \quad \mathrm{I}=1, \ldots, \mathrm{N} \quad \mathrm{t}=1,2,3
$$

where $A_{i t}=1$ if $A_{i t}^{*}>0,=0$ otherwise and $A_{i t}^{*}$ is the unobserved propensity to receive wage arrears, $\mathrm{X}$ is a vector of time varying and time invariant regressors and $\mathrm{v}$ is the error term with

$$
\mathrm{v}_{\mathrm{it}}=\mathrm{a}_{\mathrm{i}}+\mathrm{u}_{\mathrm{it}}
$$

and $a_{i}$ is the random effect, with $a_{a} \sim N\left(0, s^{2}{ }_{a}\right)$ independently of $u_{t}$ and the $X$ vector. Each disturbance term thus has variance $\operatorname{Var}\left(\mathrm{v}_{\mathrm{it}}\right)=\operatorname{Var}\left(\mathrm{s}_{\mathrm{a}}^{2}+\mathrm{s}{ }_{\mathrm{u}}^{2}\right)$ and the correlation between error terms for the same individual is given by

$$
\operatorname{Corr}\left(\mathrm{a}_{\mathrm{i}}+\mathrm{u}_{\mathrm{it}}, \mathrm{a}_{\mathrm{i}}+\mathrm{u}_{\mathrm{is}}\right)=?=\mathrm{s}_{\mathrm{a}}^{2} /\left(\mathrm{s}_{\mathrm{a}}^{2}+\mathrm{s}_{\mathrm{u}}^{2}\right)
$$

The parameters of the likelihood function, which comprises this model, are estimated using the iterative techniques in Stata. The simple pooled probit model is equivalent to assuming that $?=0$.

Consistent with the evidence from the RLFS, personal characteristics do little to influence the probability of being in arrears. The characteristics of the establishment and the region in which 
the individual lives have a much more important role. Job tenure is now a significant determinant of wage arrears, consistent with the idea that insider forces facilitate delayed wage payments. Unskilled, male, prime-age workers living in the regions furthest from the metropolitan areas, working in large scale enterprises for ten years or more are most at risk from wage arrears. An additional rural variable is also significant. This may suggest that enterprises and workers living away from the main administrative centres find it harder to plead their case. The estimated effects do not change much as we go from the simple pooling to the random effects model. In particular the firm level effects continue to dominate, which tends to rule out the idea that discrimination across individuals in the same plant is widespread.

\section{Persistence of wage arrears}

One as yet unresolved issue is how long wage arrears persist and whether the same individuals are affected over time. Rather like the stock-flow analysis of unemployment, if wage arrears were shared equally across the population, there may be less cause for concern than if arrears were concentrated on the same individuals. To address this issue we simply count the number of times an individual classifies themselves as in arrears in the RLMS, restricting our sample to those continuously in employment. ${ }^{16}$ Whilst we do not observe the start of the arrears process, we can observe inflows and outflows from the state, together with the cumulation of arrears. Table 12 shows that over the three year observation period, a combination of rising inflow rate and a falling outflow rate contribute to a rising stock of arrears in the population. The average amount of arrears grew by around $40 \%$ and the amount owed rises monotonically according to the number of years the individual is observed in arrears. Arrears are also distributed unequally. By 1996, one-quarter of the sample working population had been in arrears in each of the three waves, whilst another quarter had yet to experience any arrears. The size of the stock of arrears relative to previous wages also grows from around one month salary to 1.7 months over the period, (Table 12). Note that the median stock of arrears does not differ much between new entrants and those in arrears previously, (the final column of panel b). This suggests that those in arrears have some of their debt paid off during the year.

In order to identify the characteristics of those persistently in arrears, Table 13 presents the results of ordered probit estimates of the probability that an individual will, in wave 3 , have been observed in arrears $0,1,2$ or 3 times. This avoids the problem of introducing lagged dependent variables into a regression, which could otherwise deliver inconsistent estimates. The ordered probit results mirror the simple binary probit estimates. Unskilled, male, prime-age workers living in the regions furthest from the metropolitan areas, working in large scale enterprises for ten years or more are most at risk from multiple wage arrears. In addition, in order to distinguish between the extensive and intensive nature of arrears, we present Tobit estimates of the amount of arrears, (Tobit because those not in arrears are censored at zero). We estimate the determinants of both the total stock of arrears for each worker, indexed for inflation, and the amount of arrears relative to previous earnings, for those who are not in arrears at the start of our sample. Those not in arrears are coded zero, for both equations. The Tobit estimates (Table 14) follow the same basic pattern as for the incidence of arrears. The level of arrears, but not the relative measure, is reduced significantly by the presence of foreign ownership at the establishment. Few of the personal characteristics retain any statistical significance. Firm size,

16. The RLMS indicates that around $9.9 \%$ of those in arrears left employment one year later, compared with around $8.5 \%$ of those not in arrears. 
job tenure and region dominate. ${ }^{17}$

\section{Arrears and Mobility}

Finally, there is the question as to why, if firms don't pay wages on time, do workers not simply move elsewhere? This may, in part, be because search unemployment is not a valid outside option in all but the most dynamic labour markets. Unemployment benefits are not available to job quits and, when they are paid, ${ }^{18}$ are not large relative to average wages. Moreover, alternative employment is perhaps only available in the most dynamic regions, typically Moscow and St. Petersburg and the claim on arrears may be loosened once the worker leaves the establishment. There are therefore push effects from arrears and a dynamic outside labour market and potentially offsetting pull effects from the need or ability to recoup arrears, magnified when inflation is low, and a depressed outside labour market.

To try and capture these effects we measure three types of mobility over the course of a year. The first a movement from employment to employment with a new establishment; the second a move from employment to unemployment and the third the move from employment to nonemployment. We introduce a variable to capture whether the worker was in arrears one year earlier and run probit regressions on the determinants of these discrete events, (Table 15). The arrears variable is significant and positive only for job-to-job moves. The push influence is not offset by the inducement to stay and retain employment and/or arrears. We then interact the arrears dummy with the dummy for the metropolitan areas of Moscow and St. Petersburg. This interaction term is again significant in the job-to-job move equation. In the metropolitan areas, those in arrears are much more likely than other workers to be found in a new job one year later. Thus the exit option is only valid in a relatively prosperous labour market. Thus quits could induce firms to pay wages, but this strategy only works if there are viable outside opportunities.

\section{Implications}

The results show convincingly, in our opinion, that regional transfers of government wages in the budgetary sector are not mainly responsible for the larger incidence of wage arrears occurring in provincial regions compared to Moscow. In March 1996, the proportion in arrears across the five regions was higher in the economy as a whole than in the budgetary sector. A cynical interpretation of the large regional divergence in wage arrears could be that historically, rebellion and revolution in Russia has only been successful if carried by the central urban agglomerations. Confining the problem of wage arrears to the provinces might allow transition to proceed more smoothly. Our evidence points in this direction, as regional location is a key determinant of wage arrears independent of industry and ownership. The Moscow regional government has helped generate an environment through its reform programmes and access to the central government that allows firms to survive and even prosper. ${ }^{19}$ A larger share of foreign ownership and a more dynamic

17. The marginal effects in the Tobit regressions are given by $d E\left[y / x_{i}\right] / d x_{i}=\beta_{i} F\left(\boldsymbol{\beta}{ }^{\prime} X / s\right)$, where the estimated coefficient is scaled by the probability of being in the uncensored region.

18. Clarke, Ashwin and Borisov (1997) note that unemployment benefit arrears are now a feature in many regions.

19. Shleifer (1996) provides some evidence on how entrepreneurs differ in their perception of the reform stance of their respective regional government. Entrepreneurs in Moscow see their regional government as reformfriendly and supportive of private business activities, while provincial entrepreneurs complain about an administrative environment that is hostile to private business. 
labour market have, in turn, helped mitigate the arrears problem.

The interesting issue of whether wage arrears are essentially a ploy by managers to extract tax concessions from the central government cannot be addressed well with the household level data at our disposal. Still, one should note the large regional variation in the incidence of wage arrears and the fact that employees working for de novo private firms are, in general, as affected by wage arrears as workers in privatised and state-owned firms. Whether such evidence raises doubts about the motives of managers is certainly an open question, which we do not pursue here.

There is an argument that disputes the importance of wage arrears from the perspective of Russian employees. It states that workers tolerate wage arrears in their primary employment, because most of them hold multiple jobs with income sources in secondary and tertiary employment much more important than the income source from primary employment. Our evidence does not support this statement. Employees who face wage arrears exercise their quit option in the metropolitan centre, but not in the provincial regions. The fact that they do not do this in the provincial regions is not because they do not care about primary employment, but because they have no outside jobs to move to. The presence or absence of outside options might best explain the large regional variation of wage arrears. The incidence of wage arrears is not spurious but a reality affecting many people, making their labour market experience in transition particularly insecure.

There is also evidence of polarisation in the incidence of arrears across the working population. Some people seem to never suffer from wage arrears whilst others do so continuously. This may be due to the uneven incidence of wage arrears across sectors rather than some kind of extreme efficiency wage strategy by firms, since observable characteristics do not drive the arrears problem, nor do controls for unobserved heterogeneity alter these findings.

\section{Conclusions}

In the context of the relatively small falls in employment since the beginning of reform, the evidence on job security in Russia is quite compelling. On the quantity side, Russian workers in 1996 faced relatively secure job prospects. The overwhelming majority of employees had a permanent contract and worked full-time. There is evidence of variation in the type of employment contract across ownership type. In SOEs and privatised firms permanent employment contracts had been given to nearly $100 \%$ of the employees, whilst around $10 \%$ of the workforce in de novo private firms had to be satisfied with a fixed term or one-off contract. So, as the employment share of de novo private firms increases in future one would expect a growing share of less secure employment contracts. The evidence on new jobs, where $22 \%$ of the workforce in de novo private firms had to be satisfied with non-permanent jobs, strengthens this conclusion. It is also clear that temporary layoffs and unpaid leave affect only a very small percentage of the workforce. In addition, short-time work seems not to be a way by which Russian firms maintain employment levels. Despite major demand shocks which have put many Russian enterprises in great financial difficulties, these enterprises seem to try to hold on to their employees by offering relatively secure employment prospects. Such an impression has been formed previously on the basis of case studies (eg Metalina, 1996). The same findings are confirmed here.

However, adjustments to demand shocks seem to occur through price rather than quantity changes. Real wages fell steeply from the beginning of the reforms though had stopped falling by 1996. The new adjustment factor is now undoubtedly the systematic withholding of wage payments from workers in many industrial branches of the economy and this is now the dominant form of insecurity for many Russian workers. Moreover, wage arrears are a major problem for provincial regions and certain industrial branches of the economy. In mining, agriculture and manufacturing 
less than $50 \%$ of all employees received their wages in full and on time in March of 1996. Miners are particularly hard hit by wage arrears, with only $30 \%$ being paid in full and on time. In the capital of the Russian Federation and its surrounding Oblast, late or incomplete wage payments affected $23 \%$ of employees. In contrast, in the provincial regions of Chelyabinsk and Krasnoyarsk nearly two-thirds of all workers had to be content with such payments.

Our evidence seems to indicate that the central government sector is not directly responsible for the high levels and the large regional variation of wage arrears. A dynamic local economy can mitigate the arrears problem by providing a valid outside option with which workers can exercise the quit threat. The large regional variation in the incidence of wage arrears and the fact that workers in domestic de novo private firms are equally affected by arrears seems to provide some, albeit weak, evidence that downplays the idea that firms use wage arrears as an instrument to extract tax concessions from the government. Nevertheless, this is an establishment problem. Firm characteristics dominate individual characteristics throughout our study.

As ever, more research about Russian wage arrears is certainly needed. However, the evidence here lends support to the notion that wage arrears are an important problem, affecting more than half the working population and averaging around one and a half months earnings. This is the most apparent manifestation of insecurity currently observed in the Russian labour market. 
Table 1. Distribution of contract types by Region, Age and Gender

\begin{tabular}{|c|c|c|c|c|c|c|c|c|c|c|c|}
\hline Region & Contract & $<20$ & 21-30 & $31-40$ & 41-50 & 51-60 & $61+$ & Total & Female & Male & $\begin{array}{l}\text { New } \\
\text { Jobs }\end{array}$ \\
\hline \multirow[t]{3}{*}{ Moscow } & Permanent & 96.2 & 96.2 & 97.7 & 98.7 & 97.9 & 94.2 & 97.6 & 97.9 & 97.4 & 84.3 \\
\hline & Fixed term & 2.3 & 3.4 & 1.7 & 1.1 & 1.7 & 5.4 & 2.0 & 1.9 & 2.1 & 11.8 \\
\hline & One-off & 1.5 & 0.4 & 0.6 & 0.2 & 0.4 & 0.4 & 0.4 & 0.2 & 0.6 & 3.9 \\
\hline Moscow & Permanent & 91.6 & 96.5 & 97.6 & 98.2 & 98.4 & 95.3 & 97.4 & 97.9 & 96.8 & 86.9 \\
\hline \multirow[t]{2}{*}{ Oblast } & Fixed term & 5.6 & 3.1 & 2.2 & 1.4 & 1.3 & 4.7 & 2.2 & 1.9 & 2.6 & 11.2 \\
\hline & One-off & 2.8 & 0.4 & 0.2 & 0.5 & 0.3 & 0.0 & 0.4 & 0.2 & 0.6 & 1.9 \\
\hline \multirow[t]{3}{*}{ Krasnoyarsk } & Permanent & 94.2 & 95.8 & 96.7 & 98.2 & 96.0 & 95.1 & 96.8 & 97.2 & 96.4 & 86.9 \\
\hline & Fixed term & 5.8 & 3.9 & 2.7 & 1.6 & 3.5 & 4.9 & 2.9 & 2.6 & 3.1 & 12.0 \\
\hline & One-off & 0.0 & 0.3 & 0.6 & 0.2 & 0.5 & 0.0 & 0.3 & 0.2 & 0.5 & 1.1 \\
\hline Chuvash & Permanent & 95.4 & 97.7 & 98.8 & 97.3 & 100.0 & 100.0 & 98.1 & 98.1 & 98.1 & 91.7 \\
\hline \multirow[t]{2}{*}{ Republic } & Fixed term & 4.6 & 2.3 & 1.2 & 2.2 & 0.0 & 0.0 & 1.7 & 1.9 & 1.5 & 6.7 \\
\hline & One-off & 0.0 & 0.0 & 0.0 & 0.5 & 0.0 & 0.0 & 0.2 & 0.0 & 0.4 & 1.7 \\
\hline \multirow[t]{3}{*}{ Chelyabinsk } & Permanent & 98.4 & 98.6 & 98.3 & 98.7 & 99.6 & 95.7 & 98.5 & 98.5 & 98.6 & 93.6 \\
\hline & Fixed term & 0.0 & 0.8 & 1.1 & 1.1 & 0.4 & 4.3 & 1.0 & 1.1 & 0.9 & 4.6 \\
\hline & One-off & 1.6 & 0.6 & 0.6 & 0.2 & 0.0 & 0.0 & 0.4 & 0.3 & 0.5 & 1.8 \\
\hline
\end{tabular}

Source: Authors' calculations based on the 1996 RLFS (12 927 observations). 


\begin{tabular}{|c|c|c|c|c|c|}
\hline Explanatory Variable & Sample Mean & $d F / d x+$ & Coefficient & Robust SE & \\
\hline Married & 0.590 & 0.035 & 0.275 & 0.138 & \\
\hline Age 16-19 & 0.086 & 0.052 & 0.637 & 0.265 & $*$ \\
\hline Age $20-24$ & 0.228 & 0.040 & 0.381 & 0.183 & * \\
\hline Age 25-34 & 0.243 & 0.011 & 0.093 & 0.156 & \\
\hline Age $45-54$ & 0.138 & 0.009 & 0.076 & 0.194 & \\
\hline Age $>55$ & 0.051 & -0.128 & -0.675 & 0.237 & ** \\
\hline Children & 0.599 & -0.001 & -0.010 & 0.128 & \\
\hline \multicolumn{6}{|l|}{ Education } \\
\hline $\begin{array}{l}\text { Higher, Higher } \\
\text { Incomplete }\end{array}$ & 0.192 & -0.034 & -0.247 & 0.244 & \\
\hline Secondary Superior & 0.339 & -0.015 & -0.120 & 0.202 & \\
\hline Secondary & 0.351 & -0.001 & -0.012 & 0.207 & \\
\hline \multicolumn{6}{|l|}{ Establishment size } \\
\hline $6-25$ & 0.259 & 0.072 & 0.745 & 0.171 & $* *$ \\
\hline $26-100$ & 0.315 & 0.092 & 0.928 & 0.177 & ** \\
\hline $101-500$ & 0.191 & 0.076 & 0.920 & 0.215 & ** \\
\hline$>500$ & 0.138 & 0.079 & 1.156 & 0.286 & ** \\
\hline \multicolumn{6}{|l|}{ Hours worked } \\
\hline $0-30$ & 0.068 & -0.383 & -1.463 & 0.299 & ** \\
\hline$>40$ & 0.857 & -0.006 & -0.051 & 0.264 & \\
\hline \multicolumn{6}{|l|}{ Ownership } \\
\hline State & 0.477 & 0.062 & 0.507 & 0.147 & $* *$ \\
\hline Privatised & 0.202 & 0.069 & 0.777 & 0.192 & ** \\
\hline \multicolumn{6}{|l|}{ Industry } \\
\hline Agriculture & 0.026 & -0.133 & -0.684 & 0.338 & * \\
\hline Constructing & 0.101 & -0.053 & -0.347 & 0.228 & \\
\hline Mining/manufacturing & 0.192 & -0.024 & -0.178 & 0.214 & \\
\hline Transport & 0.072 & 0.014 & 0.128 & 0.261 & \\
\hline Distribution/Trade & 0.249 & 0.014 & 0.116 & 0.179 & \\
\hline Health/Education & 0.113 & 0.025 & 0.231 & 0.263 & \\
\hline Finance & 0.022 & -0.086 & -0.494 & 0.390 & \\
\hline \multicolumn{6}{|l|}{ Occupation } \\
\hline Other workers & 0.070 & 0.010 & 0.086 & 0.431 & \\
\hline
\end{tabular}




\begin{tabular}{|c|c|c|c|c|c|}
\hline Professional & 0.190 & 0.021 & 0.186 & 0.378 & \\
\hline Clerks & 0.054 & -0.129 & -0.684 & 0.425 & \\
\hline Production & 0.042 & 0.027 & 0.259 & 0.524 & \\
\hline Craftsmen & 0.143 & -0.073 & -0.465 & 0.402 & \\
\hline Service workers & 0.412 & -0.101 & -0.727 & 0.362 & * \\
\hline Technicians & 0.050 & 0.057 & 0.813 & 0.472 & \\
\hline Region & & & & & \\
\hline Moscow & 0.279 & -0.094 & -0.623 & 0.202 & ** \\
\hline Moscow Oblast & 0.266 & -0.082 & -0.546 & 0.208 & ** \\
\hline Chuwash Republic & 0.050 & -0.074 & -0.449 & 0.332 & \\
\hline Krasnoyarsk & 0.219 & -0.073 & -0.475 & 0.223 & * \\
\hline Constant & & & 1.044 & 0.531 & * \\
\hline Dependent Variable & & \multicolumn{4}{|c|}{ Number of obs $=1098$} \\
\hline $\begin{array}{l}y=1 \text { permanent job, } \\
y=0 \text { temporary }\end{array}$ & & \multicolumn{4}{|c|}{$\operatorname{chi2}(36)=199.86$} \\
\hline \multirow[t]{2}{*}{ Sample Mean 0.875} & & \multicolumn{4}{|c|}{ Log Likelihood $=-294.1$} \\
\hline & & Pseudo R2 & $=0.281$ & & \\
\hline
\end{tabular}


Table 3. Actual v. Usual Hours and Involuntary Part-Time Working, by Region

\begin{tabular}{|c|c|c|c|c|c|}
\hline & Less & Equal & More & Part-Time & $\begin{array}{l}\text { Involuntary } \\
\text { Part-Time }\end{array}$ \\
\hline Moscow & 4.8 & 92.2 & 3.0 & 2.9 & 62.4 \\
\hline $\begin{array}{l}\text { Moscow } \\
\text { Oblast }\end{array}$ & 5.3 & 91.9 & 2.8 & 3.0 & 84.2 \\
\hline $\begin{array}{l}\text { Krasnoyarsk } \\
\text { Chuvash }\end{array}$ & 5.9 & 87.3 & 6.7 & 5.0 & 80.5 \\
\hline Republic & 10.8 & 87.5 & 1.7 & 4.1 & 95.8 \\
\hline Chelyabinsk & 7.1 & 91.0 & 1.9 & 2.8 & 90.9 \\
\hline Total & 5.7 & 91.1 & 3.2 & 3.2 & 77.2 \\
\hline
\end{tabular}


Table 4. Wage Arrears, by Age and Gender

\begin{tabular}{llllllllll} 
Wages paid: & Total & Male & Female & $<\mathbf{2 0}$ & $\mathbf{2 1 - 3 0}$ & $\mathbf{3 1 - 4 0}$ & $\mathbf{4 1 - 5 0}$ & $\mathbf{5 1 - 6 0}$ & $\mathbf{6 1 +}$ \\
\hline RLFS & & & & & & & & & \\
In full, on time & 62.8 & 59.2 & 65.4 & 71.0 & 67.0 & 62.1 & 59.4 & 60.1 & 63.6 \\
In full, not on time & 2.7 & 3.2 & 2.2 & 1.7 & 2.7 & 2.9 & 2.4 & 3.1 & 2.0 \\
Incomplete, on time & 23.4 & 25.3 & 23.3 & 16.5 & 20.8 & 24.6 & 26.4 & 25.4 & 24.3 \\
Incomplete, not on time & 10.7 & 12.3 & 9.2 & 10.7 & 9.4 & 10.2 & 11.9 & 11.4 & 9.6 \\
RLMS & & & & & & & & & \\
In Arrears, 1994 & 40.6 & 44.4 & 37.0 & 29.3 & 36.2 & 43.9 & 43.7 & 37.9 & 34.5 \\
In Arrears, 1996 & 59.7 & 62.2 & 57.4 & 51.0 & 55.6 & 61.4 & 61.2 & 63.8 & 49.7 \\
\hline
\end{tabular}

Source: RLFS, RLMS 
Table 5. Wage Arrears, by Region

\begin{tabular}{lllllll}
\hline & Region & & & & \\
\cline { 2 - 7 } Wages paid: & Moscow & Moscow Oblast & Krasnoyarsk & Chuvash & Chelyabinsk & Total \\
\hline In full, on time & 76.8 & 71.8 & 34.7 & 42.5 & 33.7 & $\mathbf{6 2 . 3}$ \\
In full, not on time & 2.5 & 2.6 & 3.5 & 1.7 & 2.8 & $\mathbf{2 . 7}$ \\
Incomplete, on time & 15.3 & 19.4 & 39.6 & 41.7 & 39.9 & $\mathbf{2 4 . 3}$ \\
Incomplete, not on time & 5.4 & 6.2 & 22.1 & 14.2 & 23.5 & $\mathbf{1 0 . 8}$ \\
\hline
\end{tabular}

\section{Budgetary Sector}

\begin{tabular}{lllllll}
\hline & Region & & & & \\
\cline { 2 - 7 } Wages paid: & Moscow & Moscow Oblast & Krasnoyarsk & Chuvash & Chelyabinsk & Total \\
\hline In full, on time & 79.3 & 79.2 & 36.4 & 49.3 & 41.9 & $\mathbf{6 8 . 5}$ \\
In full, not on time & 2.6 & 1.4 & 3.5 & 1.8 & 4.6 & $\mathbf{2 . 5}$ \\
Incomplete, on time & 14.0 & 15.1 & 43.4 & 41.8 & 42.1 & $\mathbf{2 2 . 3}$ \\
Incomplete, not on time & 4.0 & 4.3 & 16.7 & 7.0 & 11.4 & $\mathbf{6 . 6}$ \\
\hline
\end{tabular}

\section{State Firms in Production}

\begin{tabular}{|c|c|c|c|c|c|c|}
\hline \multirow[b]{2}{*}{ Wages paid: } & \multicolumn{6}{|l|}{ Region } \\
\hline & Moscow & Moscow Oblast & Krasnoyarsk & Chuvash & Chelyabinsk & Total \\
\hline In full, on time & 62.3 & 62.7 & 23.6 & 31.2 & 25.9 & 53.1 \\
\hline In full, not on time & 3.8 & 3.9 & 4.9 & 1.3 & 1.3 & 3.6 \\
\hline Incomplete, on time & 23.7 & 25.5 & 45.5 & 42.9 & 37.9 & 29.0 \\
\hline Incomplete, not on time & 10.3 & 7.9 & 26.0 & 24.7 & 34.8 & 14.3 \\
\hline
\end{tabular}


Table 6. Wage Arrears by Industry

\begin{tabular}{|c|c|c|c|c|c|c|}
\hline \multirow[b]{2}{*}{ Wages paid: } & \multicolumn{5}{|c|}{ Industry } & \multirow[b]{2}{*}{$\begin{array}{l}\text { Distribution/ } \\
\text { trade }\end{array}$} \\
\hline & Agriculture & Manufacturing & Construction & Mining & Transport & \\
\hline In full, on time & 55.1 & 47.6 & 54.3 & 32.5 & 65.2 & 86.3 \\
\hline $\begin{array}{l}\text { In full, not on } \\
\text { time }\end{array}$ & 3.3 & 3.0 & 3.5 & 3.1 & 3.2 & 2.3 \\
\hline $\begin{array}{l}\text { Incomplete on } \\
\text { time }\end{array}$ & 21.9 & 30.8 & 29.4 & 43.1 & 24.2 & 8.6 \\
\hline $\begin{array}{l}\text { Incomplete, Not } \\
\text { on time }\end{array}$ & 19.8 & 18.5 & 12.9 & 21.2 & 7.3 & 2.7 \\
\hline \multirow[t]{2}{*}{ Empl. share } & 2.6 & 24.7 & 8.6 & 2.0 & 9.9 & 12.4 \\
\hline & Finance & Health/education & Other services & Total & & \\
\hline In full, on time & 92.4 & 68.0 & 66.9 & 63.0 & & \\
\hline In full, not on time & 1.7 & 2.4 & 2.4 & 2.7 & & \\
\hline $\begin{array}{l}\text { Incomplete, on } \\
\text { time }\end{array}$ & 4.5 & 23.8 & 22.4 & 23.8 & & \\
\hline $\begin{array}{l}\text { Incomplete, not on } \\
\text { time }\end{array}$ & 1.4 & 5.7 & 8.2 & 10.5 & & \\
\hline Empl. share & 2.3 & 14.7 & 22.7 & 100 & & \\
\hline
\end{tabular}




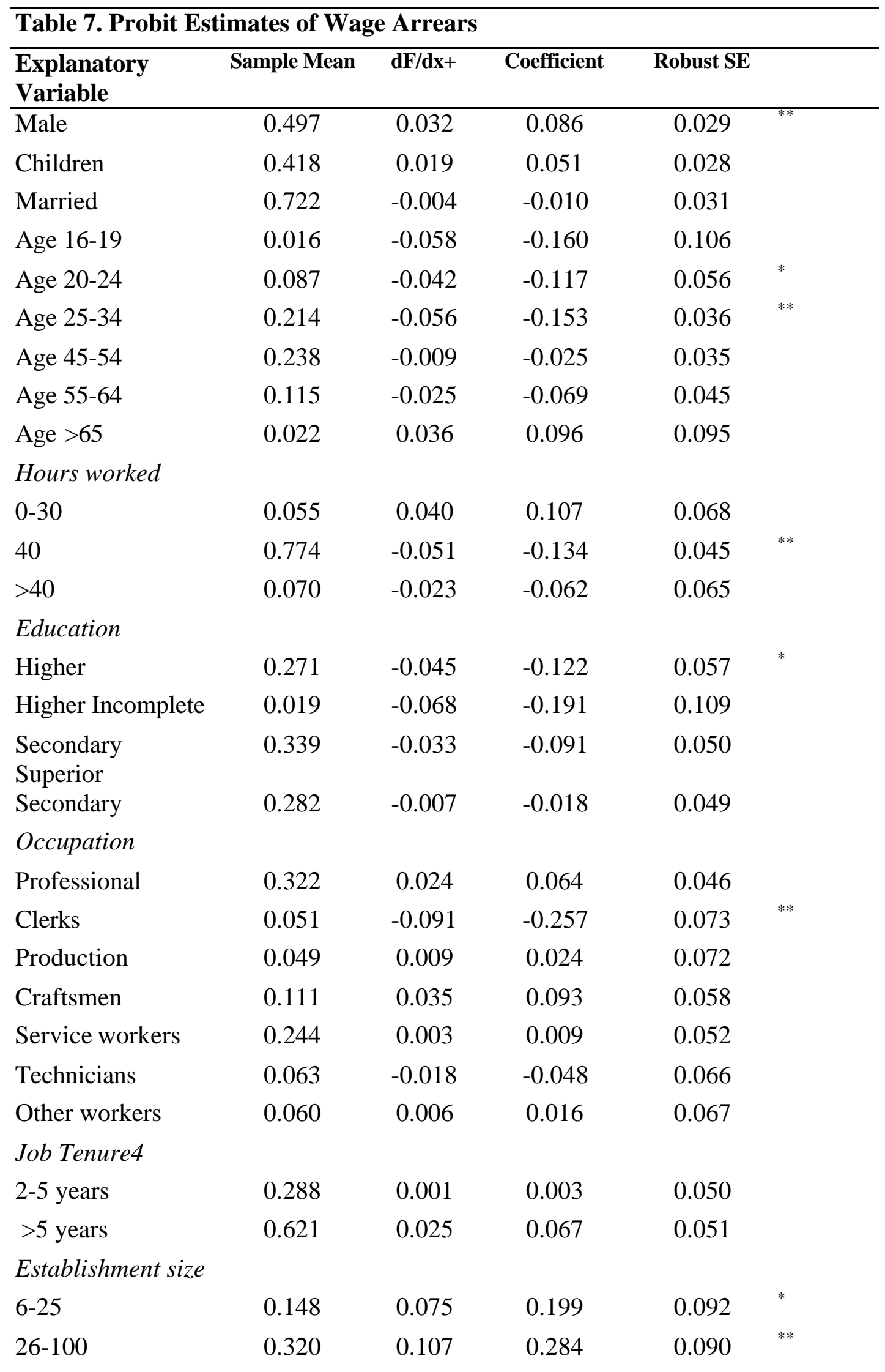




$\begin{array}{llllll}101-500 & 0.287 & 0.177 & 0.466 & 0.092 \\ >500 & 0.221 & 0.224 & 0.583 & 0.094\end{array}{ }^{* *}$

Industry

\begin{tabular}{llllll} 
Agriculture & 0.026 & -0.017 & -0.045 & 0.088 & \\
Manufacturing & 0.248 & 0.093 & 0.246 & 0.040 & $* *$ \\
Constructing & 0.087 & 0.098 & 0.257 & 0.050 & $* *$ \\
Mining & 0.020 & 0.154 & 0.395 & 0.091 & $* *$ \\
Transport & 0.100 & -0.044 & -0.120 & 0.047 & $*$ \\
Distribution/Trade & 0.126 & -0.167 & -0.495 & 0.054 & $* *$ \\
Finance & 0.023 & -0.243 & -0.832 & 0.119 & $* *$ \\
Health/Education & 0.148 & -0.055 & -0.153 & 0.047 & $* *$ \\
Ownership & & & & & \\
De Novo Private & 0.125 & -0.029 & -0.080 & 0.047 & \\
Privatised & 0.181 & -0.009 & -0.024 & 0.038 & \\
Region & & & & & \\
Moscow & 0.402 & -0.347 & -1.001 & 0.042 & $* *$ \\
Moscow Oblast & 0.292 & -0.316 & -0.960 & 0.044 & $* *$ \\
Krasnoyarsk & 0.136 & 0.004 & 0.012 & 0.051 & \\
Chuwash Republic & 0.045 & -0.053 & -0.147 & 0.069 & $*$ \\
Constant & & & 0.098 & 0.130 & \\
\hline
\end{tabular}

$\begin{array}{ll}\begin{array}{l}\text { Dependent Variable } \\ y=1, \text { wage arrears }\end{array} & \begin{array}{l}\text { Number of obs }=11900 \\ \text { chi2(43) }=2105.64\end{array} \\ y=0, \text { payment complete and in time } & \text { Prob }>\text { chi } 2=0.0000 \\ \text { Mean }=0.389 & \text { Log Likelihood }=-6621.918 \\ & \text { Pseudo R2 }=0.1571\end{array}$

r 


\section{Table 8. Probabilities of Wage Arrears for selected characteristics}

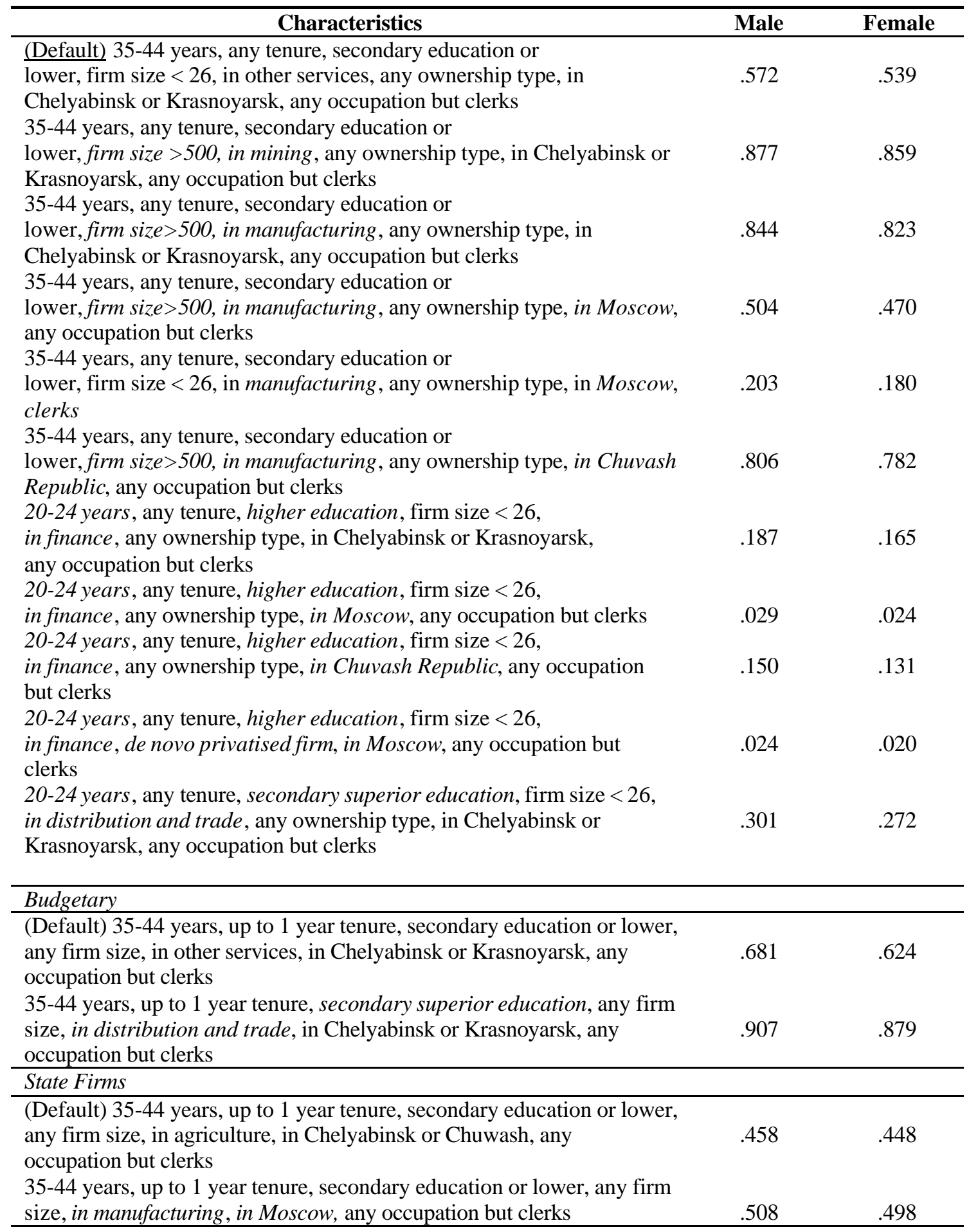

Source: Authors' calculations based on Probit regress 
Table 9

Probit Estimates of Wage Arrears by Industry

\begin{tabular}{|c|c|c|c|c|c|c|c|c|c|}
\hline Variable & $\begin{array}{c}\text { Agriculture } \\
\text { dF/dx }\end{array}$ & $\begin{array}{l}\text { Manuf. } \\
\text { dF/dx }\end{array}$ & $\begin{array}{l}\text { Constr. } \\
\text { dF/dx }\end{array}$ & & $\begin{array}{l}\text { Mining } \\
\text { dF/dx }\end{array}$ & $\begin{array}{c}\text { Transport } \\
\text { dF/dx }\end{array}$ & $\begin{array}{r}\text { Distribution/ } \\
\text { Trade } \\
\text { dF/dx }\end{array}$ & $\begin{array}{c}\text { Education/ } \\
\text { Health } \\
\text { dF/dx }\end{array}$ & $\begin{array}{r}\text { Other } \\
\text { Services } \\
\text { dF/dx }\end{array}$ \\
\hline & -0.070 & -0.038 & $0.090^{* *}$ & & 0.130 & $0.103^{* * *}$ & $0.061^{* * * *}$ & $0.063^{*}$ & 0.021 \\
\hline $\begin{array}{l}\text { Male } \\
\text { Children }\end{array}$ & 0.056 & 0.024 & -0.024 & & 0.014 & 0.006 & $0.063^{* * * *}$ & -0.018 & 0.035 \\
\hline Married & 0.009 & -0.022 & -0.070 & & 0.089 & 0.046 & -0.016 & 0.006 & 0.019 \\
\hline Age 16-19 & 0.066 & 0.115 & -0.141 & $16-24$ & 0.173 & -0.158 & -0.090 * & -0.038 & -0.090 \\
\hline Age 20-24 & 0.000 & -0.049 & $-0.140^{*}$ & & & 0.009 & -0.027 & 0.048 & -0.043 \\
\hline Age 25-34 & -0.134 & $-0.056^{*}$ & $-0.119^{* *}$ & $25-34$ & 0.002 & -0.023 & $-0.050^{* *}$ & 0.009 & $-0.075^{* * * *}$ \\
\hline Age $45-54$ & -0.089 & -0.010 & -0.063 & $45-54$ & $0.163^{* *}$ & -0.018 & 0.000 & 0.016 & 0.001 \\
\hline Age 55-64 & -0.191 & 0.027 & -0.079 & $>55$ & -0.133 & $-0.193^{* * * *}$ & -0.018 & -0.001 & 0.000 \\
\hline Age $>65$ & -0.026 & 0.034 & 0.087 & & & -0.181 & $0.206^{*}$ & 0.031 & 0.097 \\
\hline \multicolumn{10}{|l|}{ Hours worked } \\
\hline $0-30$ & $0.506^{* *}$ & 0.049 & -0.016 & & & 0.065 & -0.072 & -0.005 & 0.022 \\
\hline 40 & 0.189 & $-0.082^{* *}$ & -0.054 & & & 0.079 & $-0.120^{* * *}$ & 0.000 & $-0.111^{* * *}$ \\
\hline$>40$ & $0.528^{* * *}$ & -0.049 & -0.105 & & & 0.089 & $-0.109^{* * * *}$ & -0.036 & -0.020 \\
\hline Education & & & & Education & & & & & \\
\hline Higher & -0.243 & -0.025 & $-0.138^{*}$ & $\begin{array}{c}\text { Hig./ } \\
\text { Hig Inco. }\end{array}$ & 0.008 & $-0.108^{*}$ & -0.057 & 0.039 & -0.013 \\
\hline Higher Incomplete & & 0.037 & -0.149 & & & $-0.305^{* * *}$ & -0.031 & 0.015 & -0.002 \\
\hline Secondary Superior & -0.164 & 0.036 & -0.084 & $\begin{array}{l}\text { Secondary } \\
\text { Sup. }\end{array}$ & 0.074 & $-0.161^{* * *}$ & -0.006 & -0.014 & -0.015 \\
\hline Secondary & $-0.158^{*}$ & 0.016 & -0.014 & Secondary & -0.070 & -0.076 & -0.014 & 0.074 & 0.007 \\
\hline \multicolumn{10}{|l|}{ Occupation } \\
\hline Professional & 0.016 & 0.013 & 0.019 & & 0.147 & 0.045 & 0.026 & $0.122^{* *}$ & 0.016 \\
\hline Clerks & & -0.062 & -0.118 & & 0.069 & -0.016 & 0.056 & -0.019 & $-0.156^{* * *}$ \\
\hline Production & -0.124 & 0.005 & -0.101 & & 0.200 & 0.171 & 0.194 & 0.027 & -0.039 \\
\hline Craftsmen & 0.201 & 0.037 & $-0.126^{*}$ & & 0.200 & 0.012 & 0.027 & $0.168^{*}$ & $0.102^{* *}$ \\
\hline Service workers & 0.041 & 0.012 & $-0.138^{* *}$ & & 0.090 & 0.033 & 0.008 & 0.094 & 0.002 \\
\hline Technicians & -0.035 & 0.011 & $-0.192^{* *}$ & & -0.090 & -0.071 & -0.020 & 0.013 & 0.003 \\
\hline
\end{tabular}




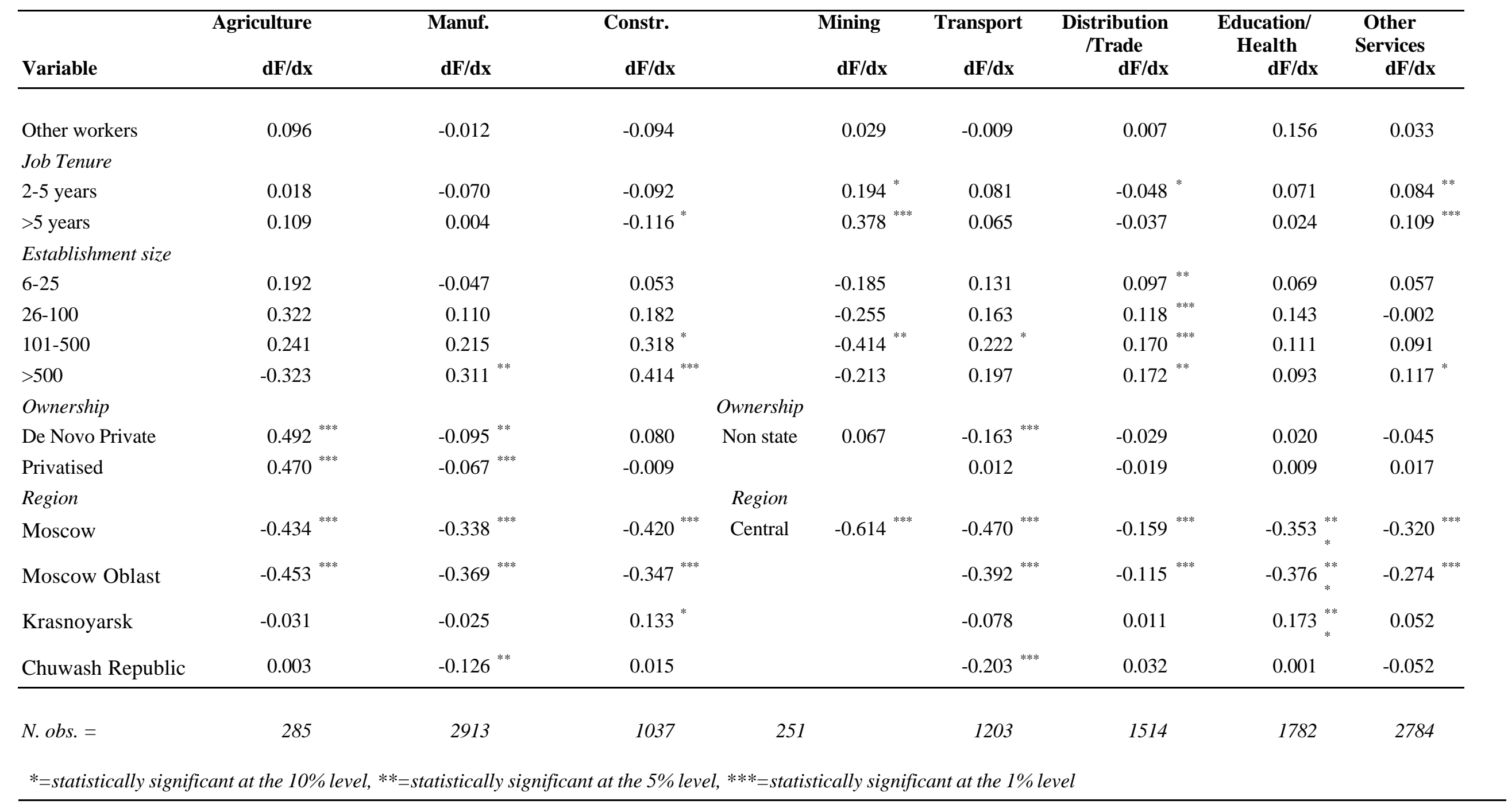


Table10-Probit Estimates of Wage Arrears by Region

\begin{tabular}{|c|c|c|c|c|c|c|c|c|c|c|}
\hline Variable & $\begin{array}{r}\text { Mo } \\
\text { dF/dx }\end{array}$ & \multirow[b]{2}{*}{${ }^{*}$} & \multicolumn{2}{|c|}{$\begin{array}{l}\text { Moscow Oblast } \\
\text { dF/dx }\end{array}$} & \multicolumn{2}{|c|}{$\begin{array}{l}\text { Krasnoyarsk } \\
\text { dF/dx }\end{array}$} & \multicolumn{2}{|l|}{$\begin{array}{l}\text { Chuvash } \\
\text { dF/dx }\end{array}$} & \multicolumn{2}{|c|}{$\begin{array}{l}\text { Chelyabsk. } \\
\text { dF/dx }\end{array}$} \\
\hline Male & 0.024 & & 0.027 & & 0.033 & & 0.035 & & 0.038 & \\
\hline Children & 0.002 & & 0.041 & ** & 0.004 & & 0.022 & & 0.002 & \\
\hline Married & 0.003 & & -0.010 & & 0.007 & & -0.040 & & 0.005 & \\
\hline Age 16-19 & -0.082 & & -0.127 & ** & -0.040 & & 0.226 & & -0.005 & \\
\hline Age $20-24$ & -0.021 & & -0.064 & ** & -0.010 & & -0.088 & & -0.025 & \\
\hline Age 25-34 & -0.031 & * & -0.101 & *** & -0.069 & * & 0.012 & & -0.004 & \\
\hline Age $45-54$ & 0.011 & & -0.010 & & -0.074 & * & -0.020 & & -0.039 & \\
\hline Age $55-64$ & -0.034 & $*$ & 0.025 & & -0.178 & $* * *$ & -0.012 & & -0.040 & \\
\hline Age $>65$ & 0.017 & & 0.086 & & 0.197 & & -0.017 & & -0.171 & $*$ \\
\hline \multicolumn{11}{|l|}{ Hours worked } \\
\hline $0-30$ & 0.105 & $* * *$ & -0.057 & & -0.121 & & 0.164 & $*$ & 0.119 & ** \\
\hline 40 & 0.002 & & -0.046 & & -0.084 & ${ }^{* *}$ & 0.047 & & -0.129 & **** \\
\hline$>40$ & -0.015 & & -0.019 & & -0.107 & $*$ & 0.122 & & -0.200 & ${ }^{*}$ \\
\hline \multicolumn{11}{|l|}{ Education } \\
\hline Higher & -0.032 & & 0.010 & & -0.121 & * & -0.227 & ${ }^{* *}$ & -0.112 & $*$ \\
\hline Higher Incomplete & -0.080 & * & 0.106 & & -0.152 & & -0.299 & ${ }^{*}$ & -0.038 & \\
\hline Secondary Superior & -0.018 & & -0.013 & & -0.008 & & -0.075 & & -0.052 & \\
\hline Secondary & -0.021 & & 0.035 & & -0.018 & & -0.072 & & -0.020 & \\
\hline \multicolumn{11}{|l|}{ Occupation } \\
\hline Professional & 0.061 & $* * *$ & 0.033 & & -0.058 & & -0.202 & $* *$ & -0.083 & \\
\hline Clerks & -0.080 & $* *$ & -0.049 & & -0.212 & $* * *$ & -0.284 & $* *$ & 0.036 & \\
\hline Production & -0.004 & & 0.051 & & -0.057 & & -0.014 & & 0.052 & \\
\hline Craftsmen & 0.043 & & 0.068 & $*$ & 0.116 & ${ }^{*}$ & -0.131 & & -0.053 & \\
\hline Service workers & -0.028 & & 0.112 & $* * *$ & 0.006 & & -0.224 & $* *$ & -0.056 & \\
\hline Technicians & -0.018 & * & 0.060 & & -0.119 & & -0.101 & & -0.079 & \\
\hline Other workers & -0.008 & & 0.045 & & 0.020 & & -0.295 & ${ }^{* *}$ & 0.063 & \\
\hline \multicolumn{11}{|l|}{ Job Tenure } \\
\hline $2-5$ years & -0.003 & & 0.023 & & 0.031 & & -0.124 & & -0.030 & \\
\hline$>5$ years & 0.016 & & -0.033 & ${ }^{* *}$ & 0.151 & ${ }^{* * * *}$ & -0.105 & & 0.073 & $*$ \\
\hline \multicolumn{11}{|l|}{ Establishment size } \\
\hline $6-25$ & 0.047 & & 0.123 & & -0.053 & & 0.198 & $* *$ & 0.117 & $*$ \\
\hline $26-100$ & 0.088 & & 0.092 & & 0.062 & & 0.102 & & 0.174 & **** \\
\hline $101-500$ & 0.187 & $* * *$ & 0.128 & $*$ & 0.095 & & 0.158 & $*$ & 0.199 & **** \\
\hline
\end{tabular}




\begin{tabular}{|c|c|c|c|c|c|c|c|c|c|c|}
\hline$>500$ & 0.252 & $* * *$ & 0.266 & ${ }^{* * * *}$ & -0.035 & & 0.085 & & 0.252 & $* * * *$ \\
\hline \multicolumn{11}{|l|}{ Industry } \\
\hline Agriculture & 0.095 & \multirow[b]{2}{*}{$* * *$} & 0.043 & \multirow[b]{2}{*}{ *** } & -0.023 & \multirow[b]{2}{*}{ *** } & 0.037 & \multirow[b]{2}{*}{$*$} & -0.319 & \multirow[t]{2}{*}{$* *$} \\
\hline Manufacturing & 0.101 & & 0.078 & & 0.112 & & 0.154 & & 0.038 & \\
\hline Constructing & 0.063 & \multirow[t]{2}{*}{$* *$} & 0.083 & ${ }^{* * * *}$ & 0.154 & \multirow{2}{*}{$\begin{array}{l}{ }^{* * * *} \\
{ }^{* * * *}\end{array}$} & 0.187 & \multirow[t]{2}{*}{$*$} & 0.112 & \multirow{2}{*}{$\begin{array}{l}* * \\
* * * \\
* *\end{array}$} \\
\hline Mining & -0.028 & & 0.088 & & 0.220 & & -0.081 & & 0.189 & \\
\hline Transport & -0.048 & \multirow[t]{2}{*}{$* *$} & -0.056 & $* *$ & -0.030 & \multirow[b]{2}{*}{$* * *$} & -0.100 & & 0.045 & \multirow[b]{2}{*}{ **** } \\
\hline Distribution/Trade & -0.080 & & -0.183 & $* * *$ & -0.228 & & -0.127 & & -0.270 & \\
\hline Finance & -0.140 & ${ }^{* * * *}$ & -0.203 & ${ }^{* * *}$ & -0.515 & $* * *$ & -0.420 & ${ }^{*}$ & -0.166 & \multirow{4}{*}{ * } \\
\hline Health/Education & -0.019 & & -0.114 & ${ }^{* * * *}$ & & & 0.137 & ${ }^{*}$ & -0.049 & \\
\hline \multicolumn{11}{|l|}{ Ownership } \\
\hline De Novo Private & -0.027 & & -0.013 & & -0.127 & $* * *$ & -0.130 & \multirow{2}{*}{$* *$} & 0.030 & \\
\hline Privatised & 0.002 & & -0.028 & & -0.047 & & -0.223 & & 0.058 & \\
\hline No. Obs. & 4945 & & 3508 & & 1358 & & 535 & & 1554 & \\
\hline \multicolumn{11}{|c|}{$*=$ significant at the $10 \%$ level } \\
\hline \multicolumn{11}{|c|}{$* *=$ significant at the $5 \%$ level } \\
\hline$* * *=$ significant $a$ & the $1 \%$ level & & & & & & & & & \\
\hline
\end{tabular}


Table 11. Monitor Probit/Random Effects Probit Estimates of Wage Arrears Probit Random Effects Probit

\begin{tabular}{|c|c|c|c|c|c|}
\hline & $\begin{array}{c}\text { Sample } \\
\text { Mean }\end{array}$ & Coefficient & $\begin{array}{c}\text { Robust } \\
\text { SE }\end{array}$ & Coefficient & $\begin{array}{c}\text { Robust } \\
\text { SE }\end{array}$ \\
\hline Male & 0.476 & 0.107 & 0.035 & 0.102 & 0.042 \\
\hline Married & 0.508 & -0.059 & 0.044 & -0.050 & 0.045 \\
\hline Dependent children & 0.578 & $0.067^{*}$ & 0.034 & 0.071 & 0.039 \\
\hline \multicolumn{6}{|l|}{ Age } \\
\hline$\overline{16-19}$ & 0.012 & $-0.315^{*}$ & 0.138 & $-0.282^{*}$ & 0.141 \\
\hline $20-24$ & 0.066 & -0.088 & 0.065 & -0.059 & 0.071 \\
\hline $25-34$ & 0.227 & 0.036 & 0.040 & 0.017 & 0.046 \\
\hline \multicolumn{6}{|l|}{$35-44$} \\
\hline $45-54$ & 0.224 & -0.006 & 0.043 & -0.019 & 0.048 \\
\hline$\geq 55$ & 0.129 & $-0.113^{*}$ & 0.052 & -0.098 & 0.060 \\
\hline \multicolumn{6}{|l|}{ Education } \\
\hline \multicolumn{6}{|l|}{$\overline{\text { Graduate School }}$} \\
\hline University/Academy & 0.193 & 0.167 & 0.165 & 0.123 & 0.197 \\
\hline Technical & 0.243 & 0.267 & 0.168 & 0.203 & 0.200 \\
\hline Trade School & 0.149 & 0.158 & 0.173 & 0.106 & 0.203 \\
\hline PTU & 0.085 & 0.158 & 0.175 & 0.134 & 0.205 \\
\hline $\begin{array}{l}\text { Any Professional } \\
\text { Course }\end{array}$ & 0.132 & 0.330 & 0.173 & 0.273 & 0.203 \\
\hline High school only & 0.189 & 0.233 & 0.171 & 0.192 & 0.202 \\
\hline \multicolumn{6}{|l|}{ Occupation } \\
\hline \multicolumn{6}{|l|}{ Managers } \\
\hline Professions & 0.018 & $-0.448^{* *}$ & 0.120 & $-0.359^{* *}$ & 0.115 \\
\hline Technicians & 0.184 & -0.032 & 0.064 & -0.000 & 0.069 \\
\hline Clerical & 0.147 & $-0.178^{* *}$ & 0.058 & -0.144 & 0.062 \\
\hline Personal Serv. & 0.073 & $-0.377^{* *}$ & 0.068 & $-0.307^{* *}$ & 0.075 \\
\hline Agric. & 0.066 & $-0.368^{* * *}$ & 0.071 & $-0.300^{* *}$ & 0.080 \\
\hline Craft & 0.005 & -0.272 & 0.214 & -0.314 & 0.246 \\
\hline Operatives & 0.178 & 0.045 & 0.056 & 0.076 & 0.062 \\
\hline Unskilled Manual & 0.201 & -0.005 & 0.055 & 0.047 & 0.060 \\
\hline \multicolumn{6}{|l|}{ Employer Size } \\
\hline$\overline{0-9}$ & & & & & \\
\hline $10-49$ & 0.204 & $0.140^{*}$ & 0.063 & 0.134 & 0.066 \\
\hline $50-99$ & 0.105 & $0.196^{* *}$ & 0.071 & $0.197^{* *}$ & 0.073 \\
\hline $100-499$ & 0.218 & $0.283^{* *}$ & 0.064 & $0.302^{* *}$ & 0.068 \\
\hline 500-999 & 0.057 & $0.320^{* *}$ & 0.083 & $0.339^{* *}$ & 0.087 \\
\hline$\geq 1000$ & 0.136 & 0.446 & 0.071 & $0.454^{* *}$ & 0.076 \\
\hline Missing & 0.207 & $0.251^{* *}$ & 0.065 & $0.242^{* *}$ & 0.068 \\
\hline \multirow{2}{*}{\multicolumn{6}{|c|}{ Length of Employment }} \\
\hline & & & & & \\
\hline 6-11 months & 0.093 & $-0.162^{*}$ & 0.072 & $-0.199^{* *}$ & 0.070 \\
\hline $12-23$ months & 0.057 & -0.041 & 0.080 & -0.057 & 0.078 \\
\hline 3-5 years & 0.101 & -0.033 & 0.069 & -0.063 & 0.066 \\
\hline 6-10 years & 0.187 & 0.087 & 0.063 & 0.074 & 0.062 \\
\hline $11-20$ years & 0.147 & $0.191^{* *}$ & 0.065 & $0.148^{*}$ & 0.064 \\
\hline$>20$ years & 0.196 & $0.182^{* *}$ & 0.063 & $0.173^{* *}$ & 0.061 \\
\hline Missing & 0.141 & $0.251^{* *}$ & 0.067 & $0.218^{* *}$ & 0.067 \\
\hline
\end{tabular}

Ownership

Private stake 


\begin{tabular}{|c|c|c|c|c|c|}
\hline State & 0.731 & $0.114^{* *}$ & 0.033 & $0.087^{* *}$ & 0.034 \\
\hline Foreign & 0.029 & -0.057 & 0.086 & -0.043 & 0.087 \\
\hline Wave 2 & 0.337 & $0.121^{*}$ & 0.048 & $0.111^{*}$ & 0.046 \\
\hline Wave3 & 0.322 & $0.566^{* *}$ & 0.049 & $0.559^{* *}$ & 0.047 \\
\hline \multicolumn{6}{|l|}{ Region } \\
\hline$\overline{\text { Moscow/St. Petersburg }}$ & & & & & \\
\hline North, North-West & 0.077 & $0.580^{* *}$ & 0.075 & $0.594^{* *}$ & 0.092 \\
\hline $\begin{array}{l}\text { Central \& Central } \\
\text { Black-Earth }\end{array}$ & 0.188 & $0.168^{* *}$ & 0.063 & $0.187^{*}$ & 0.078 \\
\hline $\begin{array}{l}\text { Black-Earth } \\
\text { Volga-Vyatsnik \& } \\
\text { Volga Basin }\end{array}$ & 0.190 & $0.550^{* *}$ & 0.063 & $0.568^{* *}$ & 0.077 \\
\hline North Caucasus & 0.118 & $0.298^{* *}$ & 0.070 & $0.321^{* *}$ & 0.085 \\
\hline Urals & 0.161 & $0.364^{* *}$ & 0.064 & $0.385^{* * *}$ & 0.079 \\
\hline Western Siberia & 0.097 & $0.485^{* *}$ & 0.071 & $0.497^{* * *}$ & 0.086 \\
\hline $\begin{array}{l}\text { East Siberia \& Far East } \\
\text { Area }\end{array}$ & 0.091 & $0.617^{* *}$ & 0.073 & $0.639^{* *}$ & 0.088 \\
\hline City & 0.068 & & & & \\
\hline Rural & 0.250 & 0.699 & 0.037 & 0.697 & 0.046 \\
\hline Constant & & $-1.251^{* *}$ & 0.203 & $-1.215^{* *}$ & 0.233 \\
\hline
\end{tabular}

\section{Probit Estimates}

mean $=0.504$

Number of observations $=8687$

$\operatorname{chi} 2(32)=1144.3$

Prob $>$ chi $2=0.0000$

Log Likelihood $=-5384.3$

Pseudo R2 $=0.106$

$*=$ significant at the $5 \%$ level

$* *=$ significant at the $1 \%$ level

\section{Random Effects Probit Estimates}

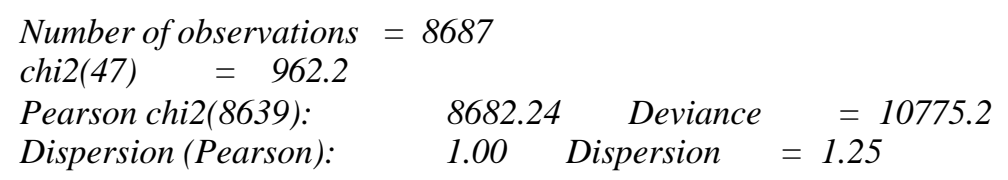


Table 12. Persistence of Wage Arrears

\begin{tabular}{|c|c|c|c|}
\hline & 1994 & 1995 & 1996 \\
\hline \multicolumn{4}{|l|}{ No. Times in Arrears } \\
\hline $\mathbf{0}$ & 60.9 & 44.2 & 26.8 \\
\hline 1 & 39.1 & 29.1 & 28.1 \\
\hline 2 & & 26.7 & 22.8 \\
\hline 3 & & & 22.3 \\
\hline \multicolumn{4}{|l|}{ Arrears (000 Rs) } \\
\hline 1 & $\begin{array}{c}826.4 \\
(912.9)\end{array}$ & $\begin{array}{c}609.0 \\
(710.9)\end{array}$ & $\begin{array}{c}846.4 \\
(862.7)\end{array}$ \\
\hline 2 & & $\begin{array}{c}908.6 \\
(952.2)\end{array}$ & $\begin{array}{l}1220.8 \\
(1142.2)\end{array}$ \\
\hline 3 & & & $\begin{array}{c}1451.9 \\
(1268.6)\end{array}$ \\
\hline Average & $\begin{array}{c}826.4 \\
(912.9) \\
\end{array}$ & $\begin{array}{c}783.5 \\
(872.8) \\
\end{array}$ & $\begin{array}{c}1176.4 \\
(1133.6) \\
\end{array}$ \\
\hline $\begin{array}{l}\text { Arrears Relative to } \\
\text { Previous Earnings } \\
\qquad 1^{\text {th }}\end{array}$ & & 0.30 & $0.60(.59)$ \\
\hline $50^{\text {th }}$ & & 1.03 & $1.70(1.68)$ \\
\hline $90^{\text {th }}$ & & 2.70 & $6.30(6.17)$ \\
\hline Arrears Outflow (\%) & & 29 & 15 \\
\hline Arrears Inflow (\%) & & 29 & 46 \\
\hline
\end{tabular}

Source: RLMS. Standard errors in brackets 


\section{Table 13. Monitor Ordered Probit Estimates of Incidence of Wage Arrears}

\begin{tabular}{|c|c|c|}
\hline Variable & Coefficient & Standard Error \\
\hline Female & -.101 & $.052 *$ \\
\hline Married & -.057 & .054 \\
\hline Dependent Children & .074 & .052 \\
\hline \multicolumn{3}{|l|}{ Age } \\
\hline$\overline{20-24}$ & -.203 & $.115 * *$ \\
\hline $25-34$ & -.003 & .061 \\
\hline \multicolumn{3}{|l|}{$35-44$} \\
\hline $45-54$ & .028 & .065 \\
\hline$\geq 55$ & -.116 & .080 \\
\hline \multicolumn{3}{|l|}{ Education } \\
\hline$\overline{\text { University/Academy }}$ & .143 & $.087 *$ \\
\hline Technical & -.011 & .071 \\
\hline Trade School & .014 & .078 \\
\hline PTU & -.197 & $.093 * *$ \\
\hline Any Professional Course & .092 & .081 \\
\hline \multicolumn{3}{|l|}{ Occupation } \\
\hline Managers & -.394 & .262 \\
\hline Professions & -.029 & .085 \\
\hline Technicians & -.106 & .077 \\
\hline Clerical & -.390 & $.094 * *$ \\
\hline Personal Serv. & -.345 & $.105 * *$ \\
\hline Agric. & -.298 & .304 \\
\hline Craft & .077 & .067 \\
\hline \multicolumn{3}{|l|}{ Employer Size } \\
\hline $0-9$ & -.487 & $.115 * *$ \\
\hline $10-49$ & -.383 & $.081 * *$ \\
\hline $50-99$ & -.291 & $.090 * *$ \\
\hline $100-499$ & -.128 & .076 \\
\hline $500-999$ & -.168 & .106 \\
\hline \multicolumn{3}{|l|}{$\geq 1000$} \\
\hline Missing & -.180 & $.082 * *$ \\
\hline \multicolumn{3}{|l|}{ Length of Employment } \\
\hline $0-5$ months & -.225 & $.131 *$ \\
\hline 6-11 months & -.153 & .142 \\
\hline 12-23 months & -.183 & $.108 *$ \\
\hline $3-5$ years & -.207 & $.081 * *$ \\
\hline $6-10$ years & -.111 & .084 \\
\hline $11-20$ years & -.061 & .079 \\
\hline \multicolumn{3}{|l|}{$>20$ years } \\
\hline Missing & -.273 & $.093 * *$ \\
\hline \multicolumn{3}{|l|}{ Ownership } \\
\hline \multicolumn{3}{|l|}{ Private stake } \\
\hline State & .153 & $.052 * *$ \\
\hline Foreign & -.107 & .126 \\
\hline \multicolumn{3}{|l|}{ Region } \\
\hline \multicolumn{3}{|l|}{$\overline{\text { Moscow/St. Petersburg }}$} \\
\hline North, North-West & .592 & $.114 * *$ \\
\hline Central \& Central Black-Earth & .181 & $.095 *$ \\
\hline Volga-Vyatsnik \& Volga Basin & .552 & $.096 * *$ \\
\hline North Caucasus & .292 & $.108 * *$ \\
\hline Urals & 395 & $.098 * *$ \\
\hline
\end{tabular}




$\begin{array}{lll}\text { Western Siberia } & .582 & .109 * * \\ \begin{array}{l}\text { East Siberia \& Far East } \\ \text { Area }\end{array} & .625 & .112^{* *} \\ \text { Rural } & .819 & .059 * * \\ & & \\ \mathrm{Mu}(1) & -.584 & .148^{* *} \\ \mathrm{Mu}(2) & .176 & .148^{* *} \\ \mathrm{Mu}(3) & .885 & .148^{* *} \\ \mathrm{Chi2}(42) & & \\ \text { Pseudo R2 } & 458.5 & \\ \mathrm{~N} & .065 & \end{array}$

$* *=$ significant at the $5 \%$ level $*$ significant at $10 \%$ level 
Table 14. Tobit Estimates of Real and Relative Wage Arrears

\begin{tabular}{|c|c|c|c|c|c|c|}
\hline \multirow[b]{3}{*}{ Female } & \multicolumn{3}{|l|}{ Real } & \multicolumn{3}{|c|}{ Relative } \\
\hline & Coefficient & S.E. & \multirow{2}{*}{$\frac{d y / d x}{-2071}$} & \multicolumn{2}{|c|}{ Coefficient S.E. } & \multirow{2}{*}{$\begin{array}{r}\mathbf{d y} / \mathbf{d x} \\
-069\end{array}$} \\
\hline & -403.8 & $102.4 * *$ & & -.194 & .409 & \\
\hline Married & 78.91 & 110.4 & 40.5 & -.281 & .441 & -.100 \\
\hline One or more children & 100.5 & 102.8 & 51.5 & .284 & .410 & .102 \\
\hline Age $20-24$ & 19.077 & 210.7 & 9.78 & -.072 & .838 & -.026 \\
\hline Age $25-34$ & -61.631 & 118.5 & -31.6 & .065 & .491 & .023 \\
\hline \multicolumn{7}{|l|}{ Age 35-44 } \\
\hline Age $45-54$ & -12.155 & 127.6 & -6.23 & -.331 & .514 & -.118 \\
\hline Age $\geq 55$ & -44.554 & 156.1 & -22.8 & -.198 & .624 & -.071 \\
\hline \multicolumn{7}{|l|}{ Education } \\
\hline$\overline{\text { University/Academy }}$ & -184.9 & 170.6 & -94.8 & -.863 & .673 & -.308 \\
\hline Technical & -55.82 & 136.5 & -28.6 & -.044 & .558 & -.016 \\
\hline Trade School & -117.6 & 153.2 & -60.3 & .021 & .635 & .008 \\
\hline PTU & -233.4 & 183.1 & -119.7 & .705 & .724 & .252 \\
\hline Any Professional Course & 150.1 & 158.1 & 76.9 & .147 & .685 & .056 \\
\hline \multicolumn{7}{|l|}{ High school only } \\
\hline \multicolumn{7}{|l|}{ Occupation } \\
\hline$\overline{\text { Managers }}$ & 7.743 & 609.8 & 3.97 & 3.117 & 1.945 & 1.114 \\
\hline Professions & 276.0 & 166.6 & 141.5 & .407 & .661 & .146 \\
\hline Technicians & -62.95 & 148.9 & -32.3 & -.009 & .602 & -.003 \\
\hline Clerical & -491.5 & $188.8 * *$ & -251.9 & -.985 & .733 & -.352 \\
\hline Personal Serv. & -461.0 & $205.9 * *$ & -236.4 & -1.531 & $.814 *$ & -.547 \\
\hline Agriculture & -367.6 & 691.6 & -188.5 & -.892 & 2.427 & -.319 \\
\hline Craft & 260.3 & $130.8 * *$ & 133.5 & .593 & .547 & .212 \\
\hline \multirow{2}{*}{\multicolumn{7}{|c|}{$\begin{array}{l}\text { Unskilled Manual } \\
\text { Employer Size }\end{array}$}} \\
\hline & & & & & & \\
\hline $0-9$ & -1271.7 & $221.9 * *$ & -652.0 & -2.595 & $.916 * *$ & -.928 \\
\hline $10-49$ & -988.3 & 156.5 & -506.7 & -1.681 & $.644 * *$ & -.601 \\
\hline $50-99$ & -568.1 & $171.4 * *$ & -291.3 & -.091 & .686 & -.032 \\
\hline $100-499$ & -349.0 & $144.9 * *$ & -178.9 & .532 & .593 & .191 \\
\hline $500-999$ & -765.8 & $210.9 * *$ & -392.7 & -1.120 & .836 & -.400 \\
\hline \multicolumn{7}{|l|}{$\geq 1000$} \\
\hline Missing & -779.2 & $158.6 * *$ & -399.5 & -1.327 & $.657 * *$ & -.474 \\
\hline \multicolumn{7}{|l|}{ Length of Employment } \\
\hline $0-5$ months & -916.4 & $225.2 * *$ & -469.8 & -3.641 & $.951 * *$ & -1.301 \\
\hline 6-11 months & -674.1 & $235.1 * *$ & -345.6 & -2.189 & $1.017 * *$ & -.783 \\
\hline $12-23$ months & -541.9 & $186.8 * *$ & -277.8 & -2.080 & $.760 * *$ & -.744 \\
\hline 3-5 years & -317.1 & $158.7 * *$ & -162.6 & -1.008 & .631 & -.360 \\
\hline $6-10$ years & -165.0 & 166.0 & -84.6 & -.437 & .667 & -.156 \\
\hline $11-20$ years & -75.7 & 155.5 & -38.8 & -.530 & .625 & -.189 \\
\hline \multicolumn{7}{|l|}{$>20$ years } \\
\hline Missing & -580.7 & 192.4 & -297.7 & -2.581 & $.790 * *$ & -.922 \\
\hline \multicolumn{7}{|l|}{ Ownership } \\
\hline \multicolumn{7}{|l|}{ Private stake } \\
\hline State & 169.4 & $101.5 *$ & 86.8 & 1.021 & $.408 * *$ & .365 \\
\hline Foreign & -535.8 & $262.9 * *$ & -274.7 & -.918 & 1.025 & -.328 \\
\hline \multicolumn{7}{|l|}{ Region } \\
\hline \multicolumn{7}{|l|}{ Moscow/St. Petersburg } \\
\hline North, North-West & 1851.4 & $222.1 * *$ & 949.3 & 3.292 & $.887 * *$ & 1.176 \\
\hline
\end{tabular}




\begin{tabular}{|c|c|c|c|c|c|c|}
\hline Central & 213.3 & 190.2 & 109.4 & 1.203 & $.711 *$ & .430 \\
\hline Volga \& Volga Basin & 615.4 & $190.9 * *$ & 315.5 & 3.039 & $.723 * *$ & 1.086 \\
\hline North Caucasus & 780.9 & $208.9 * *$ & 400.4 & 3.289 & $.803 * *$ & 1.176 \\
\hline Urals & 777.4 & $192.3 * *$ & 398.6 & 2.891 & $.723 * *$ & 1.033 \\
\hline Western Siberia & 1011.9 & $212.2 * *$ & 518.9 & 1.902 & $.845 * *$ & .680 \\
\hline $\begin{array}{l}\text { East Siberia \& Far East } \\
\text { Area }\end{array}$ & 1483.3 & $220.1 * *$ & 760.5 & 3.724 & $.898 * *$ & 1.331 \\
\hline Rural & 463.2 & $114.9 * *$ & 237.5 & 1.192 & $.536 * *$ & .426 \\
\hline Constant & 222.4 & 284.2 & & -3.217 & $1.141 * *$ & \\
\hline Standard Error & 1911.7 & $38.08 * *$ & & 5.938 & $.175 * *$ & \\
\hline Pseudo R2 & 0.014 & & & 0.031 & & \\
\hline Chi 2 (42) & 375.5 & & & 169.6 & & \\
\hline$N$ & 2462 & & & 1723 & & \\
\hline Censored & 1042 & & & 1042 & & \\
\hline
\end{tabular}


Table 15. Probit Estimates of Effect of Wage Arrears on Mobility

\begin{tabular}{|c|c|c|c|c|c|c|c|c|c|}
\hline & \multicolumn{3}{|c|}{ Job-to-Job } & \multicolumn{3}{|c|}{ E to Non-Employment } & \multicolumn{3}{|c|}{ E to Unemployment } \\
\hline & Coef. & S.E. & Marginal & Coef. & S.E. & Marginal & Coef. & S.E. & Marginal \\
\hline Arrears last year & $0.210 *$ & 0.061 & 0.023 & -0.011 & 0.057 & -0.002 & -0.003 & 0.074 & -0.002 \\
\hline Arrears*Mosc./St. P. & $0.448 * *$ & 0.195 & 0.066 & -0.159 & 0.228 & -0.025 & -0.239 & 0.282 & -0.016 \\
\hline$\underline{\text { Region }}$ & & & & & & & & & \\
\hline$\overline{\text { Moscow/St. Petersbg. }}$ & & & & & & & & & \\
\hline North, North-West & -0.102 & 0.154 & -0.010 & 0.007 & 0.171 & 0.001 & -0.124 & 0.218 & -0.009 \\
\hline Central & -0.081 & 0.133 & -0.008 & $0.242 *$ & 0.144 & 0.045 & 0.148 & 0.181 & 0.012 \\
\hline Volga \& Volga Basin & -0.097 & 0.135 & -0.009 & 0.120 & 0.148 & 0.022 & -0.218 & 0.193 & -0.015 \\
\hline North Caucasus & -0.140 & 0.149 & -0.013 & $0.293^{*}$ & 0.153 & 0.058 & 0.253 & 0.193 & 0.024 \\
\hline Urals & -0.047 & 0.137 & -0.004 & 0.155 & 0.148 & 0.028 & -0.040 & 0.189 & -0.003 \\
\hline Western Siberia & -0.216 & 0.153 & -0.019 & 0.130 & 0.161 & 0.024 & 0.037 & 0.202 & 0.003 \\
\hline East & 0.043 & 0.151 & 0.005 & 0.044 & 0.166 & 0.008 & -0.025 & 0.215 & -0.002 \\
\hline Area & & & & & & & & & \\
\hline Rural & $-0.230 * *$ & 0.075 & -0.022 & 0.095 & 0.068 & 0.017 & -0.124 & 0.095 & -0.009 \\
\hline Ownership & & & & & & & & & \\
\hline State & $-0.216 * *$ & 0.060 & -0.025 & & & -0.019 & & & -0.004 \\
\hline Foreign & 0.076 & 0.139 & 0.008 & & & -0.013 & & & 0.001 \\
\hline Constant & $-2.043 * *$ & 0.292 & & $-1.708 * *$ & 0.318 & & -1.872 & $0.487 * *$ & \\
\hline Pseudo R2 & 0.087 & & & 0.070 & & & 0.070 & & \\
\hline Chi 2 (46) & 231.3 & & & 201.9 & & & 94.0 & & \\
\hline Mean Dep. Var. & 0.067 & & & 0.113 & & & 0.046 & & \\
\hline$N$ & 5313 & & & 4328 & & & 4060 & & \\
\hline
\end{tabular}


Figure 1

Dynamics of Real Wages and Real Wage Arrears 1994/1996

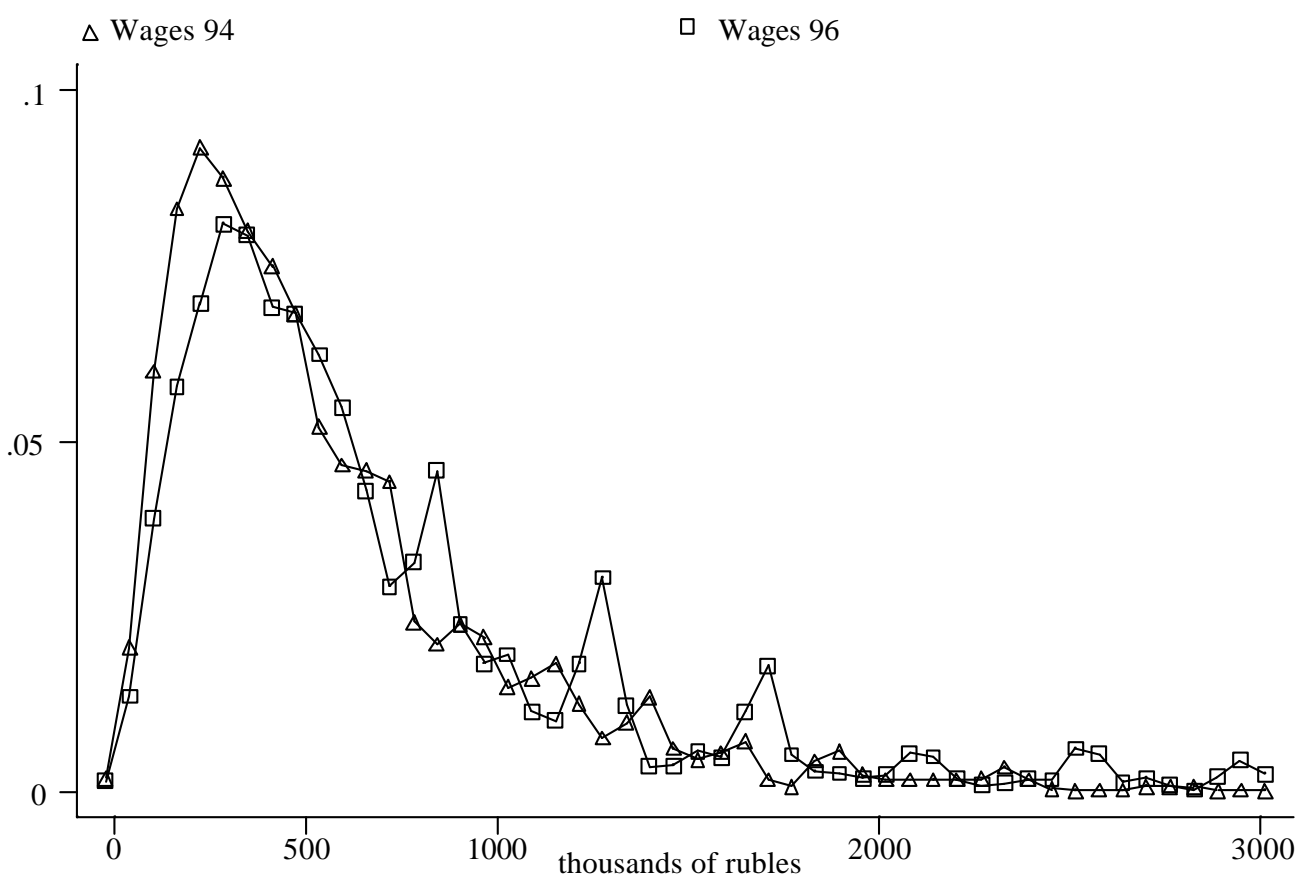

$\triangle$ Arrears 94

$\square$ Arrears 96

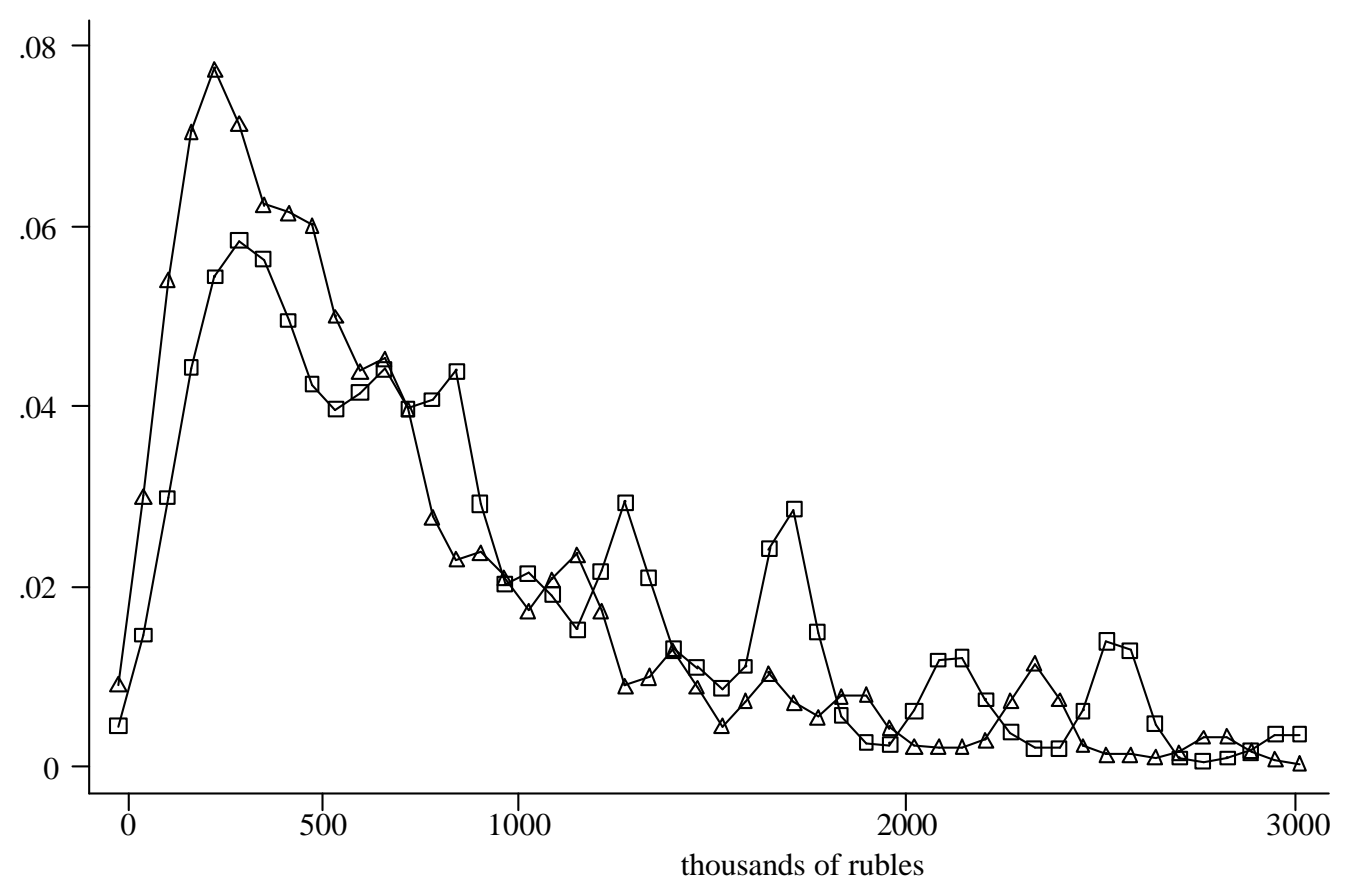


Figure 2

Wage Arrears Relative to Monthly Wages - 1994/1996

$\Delta$ Wages 94

$\square$ Arrears 94

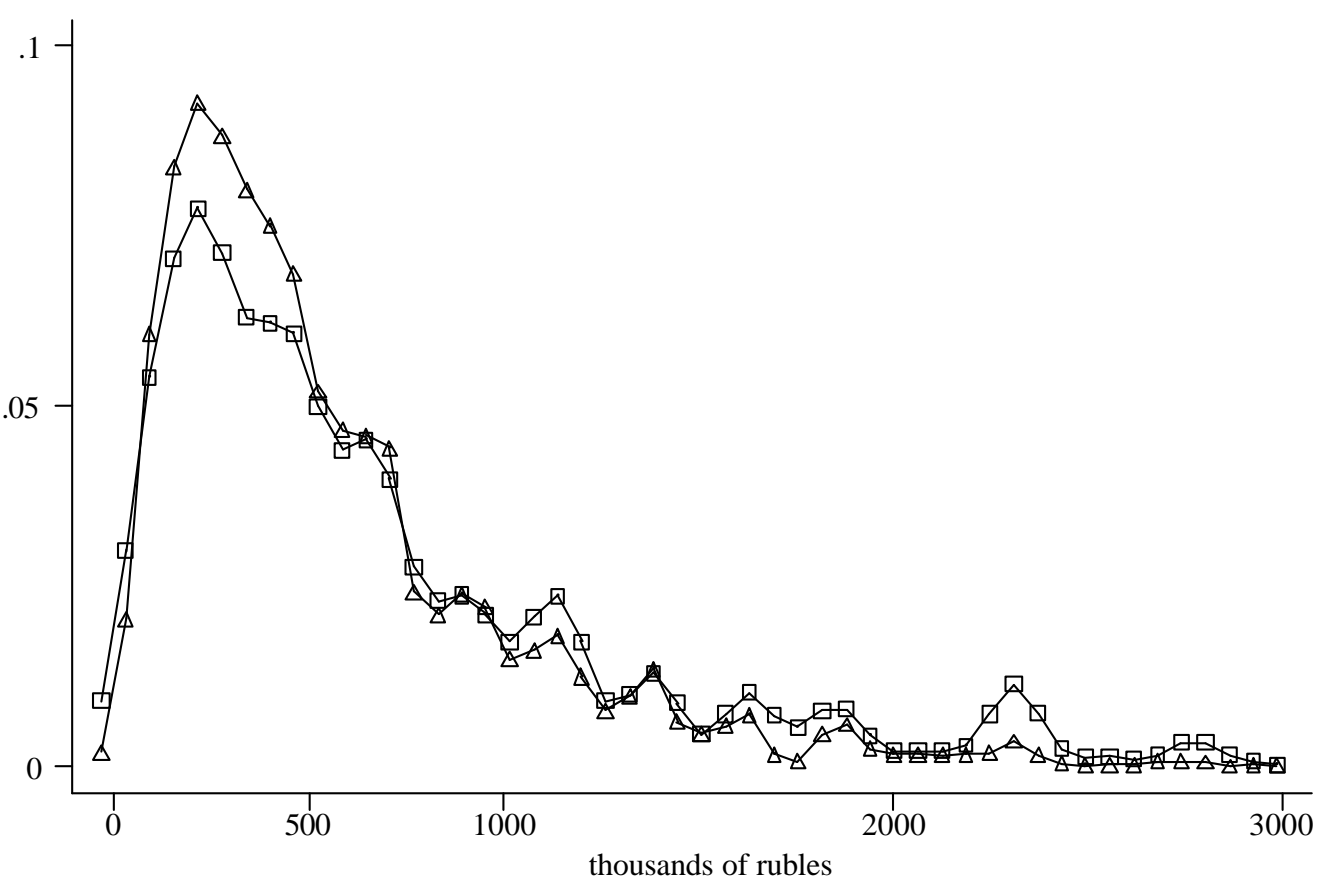

$\Delta$ Wages 96

$\square$ Arrears 96

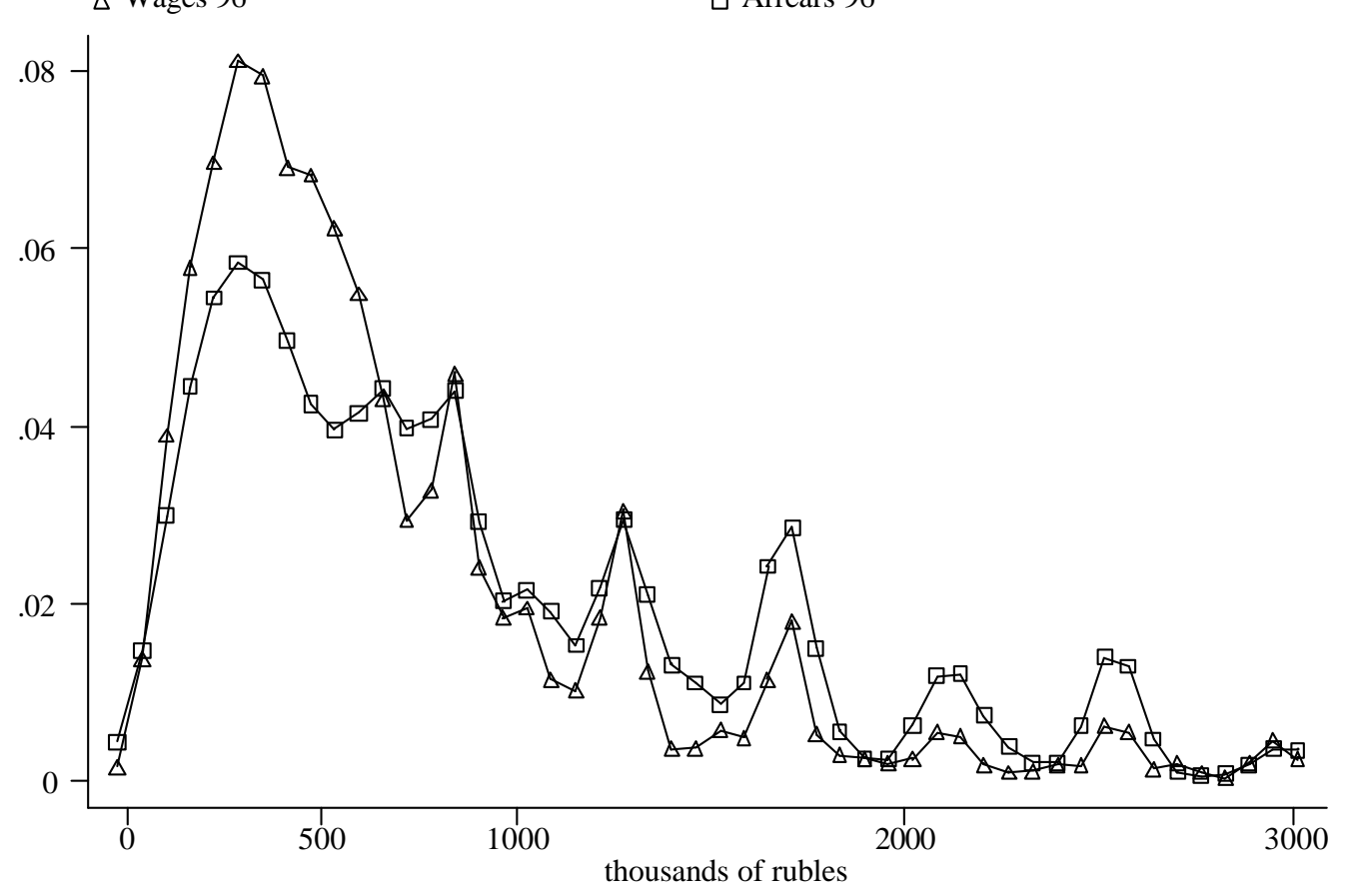

Source: Authors' calculations based on the RLMS.

Figure 3

Comparison of Wage Distributions of those Unaffected Affected by Wage Arrears 
Wages in 1994

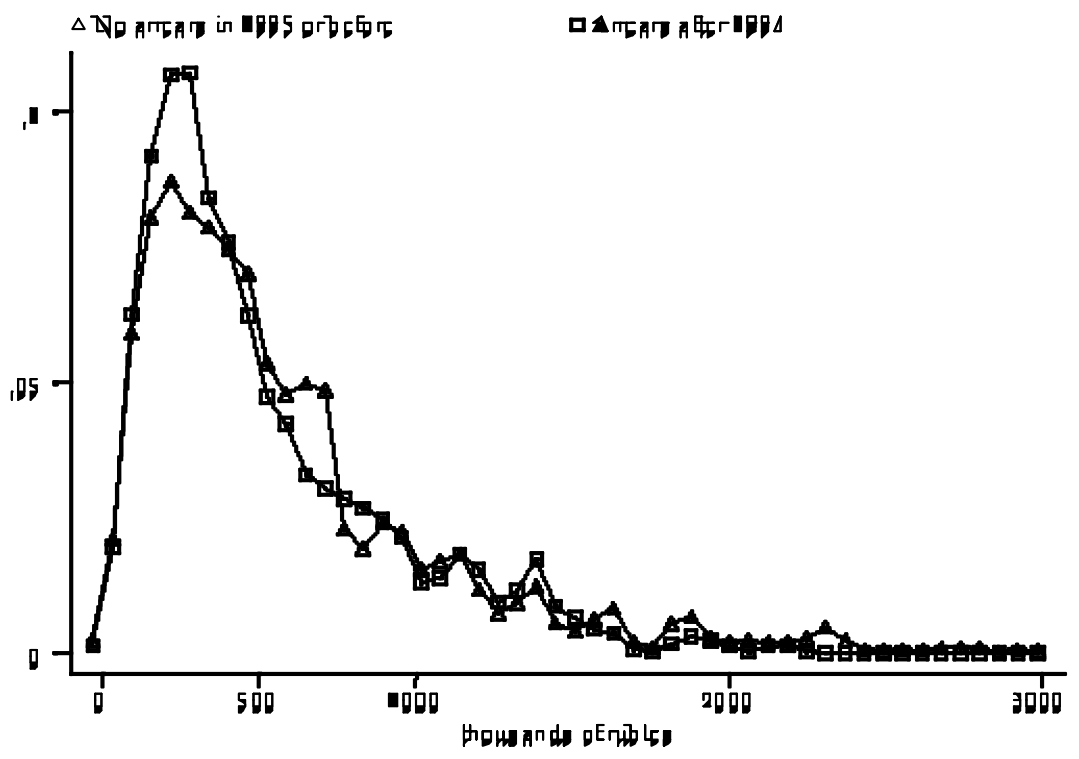

Wages in 1995

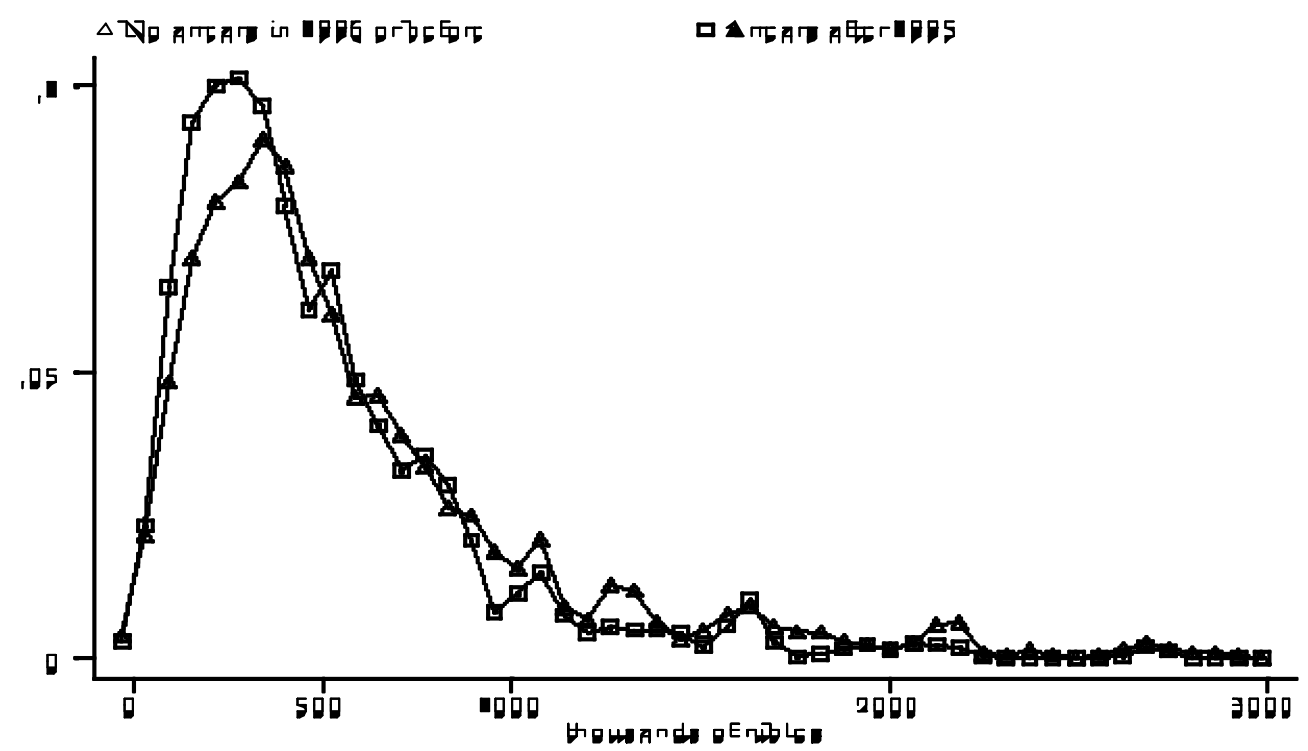

Source: Authors' calculations based on the RLMS. 


\section{Data Appendix: Regional labour market types in the Russian Federation}

This annex gives a brief overview of regions selected for this study as being representative of the main regional labour market types in Russia.

The City of Moscow, while interesting as a labour market in its own right given its status as the capital of the Russian Federation, is also representative of a region with a diversified industrial base, like machine building, light and food industries, production of construction materials and with a developed construction sector. The infrastructure of social services is relatively good, and large centres of science, medicine, education and culture can be found here. Private market structures are also more developed, hence the private employment share is higher than in other regions. Demographically, this type is characterised by low natural population growth and little migration activity. The registered unemployment rate is substantially lower than the average rate in Russia.

Moscow Oblast, which surrounds Moscow City, is representative of mixed urban-rural areas with good links to major cities as well as adjacent districts with economies based on agriculture or forestry. Such regions benefit from spill-over from nearby cities, have significant industrial or scientific concentrations, contain substantial agricultural activities including food processing, and have lower costs of living than urban areas. Generally, such regions have significant growth potential based not only on existing enterprises, but on the development of greenfield sites and access to labour from adjacent regions within commuting distance. This potential has been only partially realised in comparison with the cities at their core. Investment flows have been stronger in the city centres and unemployment is higher in the urban-rural transition regions.

Chelyabinsk Oblast is representative of regions dominated, at least historically, by the military-industrial complex. Huge enterprises of heavy industry are concentrated there, especially machine building and metallurgy, and are mainly related to defence. There are many settlements in these regions where the labour force is entirely dependent on these enterprises. The low rates of restructuring and conversion of production, plus the dependence on deliveries of semi-finished products and energy from the outside, have been major determinants in the dramatic drop of production. A high level of employment has been maintained until 1996 through support for some industries from the federal budget.

The Chuvash Republic reflects the economic situation of agro-industrial areas where processing plants are the main form of industrial enterprise. These areas are not well endowed with minerals and energy sources. Agriculture is geared mainly towards vegetable growing and cattle breeding and is carried out under economically, and often also ecologically, suspect conditions. A relatively high natural population growth and a low degree of labour mobility can exists in these regions. The fall in industrial and agricultural production is greater than the average in the Russian Federation. The infrastructure of social services is underdeveloped while the level of registered unemployment is much higher than the Russian average.

Krasnoyarski Krai is typical of the industrially developed regions dominated by extraction industries, such as oil and gas, timber production, fisheries and fish processing. Agriculture is practically absent. Output has fallen less rapidly than the average for the Federation. The demographic situation is characterised by a low rate of natural population growth and a high level of outward migration to more favoured areas of the country, which has risen substantially during the years of economic reform. Most of these regions are in the northern European and Asian parts of the country and make up a considerable proportion of the Russian Federation.

\section{List of relevant supplement questions}

\section{Personal characteristics}

How many children do you have?

How many other dependent persons do you care for?

\section{Wage arrears}

For which month were you last paid? 
Did you receive this wage complete and in time? In time but incomplete? Complete but with delay? Incomplete and with delay?

\section{Wages}

What was your gross monthly salary (money or products; and if applicable premia) from your principal job for the last month you were paid?

\section{Tenure}

How long have you continuously been employed by your current employer?

\section{Establishment size}

How many employees are there at the place where you work?

\section{Industry}

In which industry are you employed?

\section{Ownership type}

What is the ownership of the firm you work for? 


\section{References}

Alfandari, G. and Schaffer, M. E. (1996) 'Arrears in the Russian Enterprise Sector', in Commander, S., Fan, Q. and Schaffer, M.E. (eds.) Enterprise Restructuring and Economic Policy in Russia, EDI/World Bank.

Commander, S. McHale, J. and Yemtsov, R. (1995) 'Russia', in Commander, S. and Coricelli, F. (eds.), Unemployment, Restructuring, and the Labor Market in Eastern Europe and Russia, EDI/World Bank.

Commander, S. Dhar, S. and Yemtsov, R. (1996) 'How Russian Firms Make Their Wage and Employment Decisions', in Commander, S., Fan Q. and Schaffer, M.E. (eds.), Enterprise Restructuring and Economic Policy in Russia, EDI/World Bank.

Clarke, S. Ashwin, S. and Borisov, B. (1997) 'The non-payment of wages in Russia', ICFTU Position Paper.

Desai, P. and Idson, T. (1997) 'The Non-Payment Crisis in Russia', Columbia University Economics Department Working Paper, July.

Foley, M. (1995) 'Labor Market Flows in Russia: Evidence from the Russian Longitudinal Monitoring Survey', World Bank, March, mimeo.

Gimpelson, V. and Lippoldt, D. (1996) ‘Labour Restructuring in Russian Enterprises: A Case Study', OECD, Paris.

Gordon, L.A. (1997) Polozhenie naiemnykh pabotnikov b Rossii 90-kh godov (Dependent Workers in Russia in the Nineties), Moscow, IMEMO.

Gregg, P. and Wadsworth, J. (1996) 'Mind the Gap? The Changing Nature of Entry Jobs in Britain', Centre for Economic Performance Discussion Paper No. 303.

Gosudarstvenyj Komitet Rossijskoj Federacii Po Statistike (Gostkomstat) (1996a) 'Rynok truda Rossijskoj Federacii v 1996 godu' ('The Labour Market of the Russian Federation in 1996'), Informacionyi statisticzeskij bjuletten, No. 13, November 1996, 45-64.

Gosudarstvenyj Komitet Rossijskoj Federacii Po Statistike (Gostkomstat) (1996b) 'O differenciacii zarabotnoj platy rabotajushchych na predprijatjach (organizacjach) v I polugodii 1996 goda' ('The Differentiation of wages of workers in enterprises (organisations) during the first half of 1996'), Informacionyj statisticzeskij bjuletten, No. 13, November 1996, 65-82.

Hanson, P. (1986) 'The Serendipitous Soviet Achievement of Full Employment: Labour Shortage and Labour Hoarding in the Soviet Economy', in Lane D. (ed.) Labour and Employment in the USSR, Brighton.

Layard, R. and Richter, A. (1995) 'How much unemployment is needed for restructuring: the Russian experience', Economics of Transition, Volume 3 (1), 39-58.

Malle, S. (1990) Employment Planning in the Soviet Union: Continuity and Change, London.

Metalina, T. (1996) 'Employment Policy in an Industrial Enterprise', in Clark, S. (ed.), Labour Relations in Transition. Wages, Employment and Industrial Conflict in Russia, Cheltenham.

Nuti, D. M. (1986) 'Systemic Aspects of Employment and Investment in Soviet-Type Economies', in Lane D. (ed.) Labour and Employment in the USSR, Brighton.

Richter, A. and Schaffer, M. E. (1996) 'The Performance of De novo Private firms in Russian Manufacturing', Centre for Economic Reform and Transformation Discussion Paper No. 96/10, Edinburgh. 
Russian Economic Trends $(1995,1997)$ Russian European Centre for Economic Policy.

Shleifer, A. (1996) 'Government in Transition’, European Economic Review, 41, 385-410.

Standing, G. (1996a) Russian Unemployment and Enterprise Restructuring. Reviving Dead Souls, ILO, Geneva.

Standing, G. (1996b) 'The Shake-Out in Russian Factories: The RLFS Fifth Round, 1995', ILO Labour Market Papers No. 14, ILO, Geneva. 
